\title{
IMPACTO DOS EVENTOS OCORRIDOS ANTES E APÓS O PARTO SOBRE O DESEMPENHO PRODUTIVO E REPRODUTIVO NA LACTAÇÃO ATUAL E NA POSTERIOR DE VACAS HOLANDESAS
}

\section{KARYNE OLIVEIRA COELHO}

Dissertação apresentada à Escola Superior de Agricultura "Luiz de Queiroz", Universidade de São Paulo, para obtenção do título de Mestre em Agronomia, Área de Concentração: Ciência Animal e Pastagens.

P I R A C I C A B A

Estado de São Paulo - Brasil

Março - 2004 


\section{IMPACTO DOS EVENTOS OCORRIDOS ANTES E APÓS O PARTO SOBRE O DESEMPENHO PRODUTIVO E REPRODUTIVO NA LACTAÇÃO ATUAL E NA POSTERIOR DE VACAS HOLANDESAS}

\section{KARYNE OLIVEIRA COELHO}

Médico Veterinário

Orientador: Prof. Dr. PAULO FERNANDO MACHADO

Dissertação apresentada à Escola Superior de Agricultura "Luiz de Queiroz", Universidade de São Paulo, para obtenção do título de Mestre em Agronomia, Área de Concentração: Ciência Animal e Pastagens.

P I R A C I C A B A

Estado de São Paulo - Brasil

Março - 2004 


\section{Dados Internacionais de Catalogação na Publicação (CIP) DIVISÃO DE BIBLIOTECA E DOCUMENTAÇÃO - ESALQ/USP}

\section{Coelho, Karyne Oliveira}

Impacto dos eventos ocorridos antes e após o parto sobre o desempenho produtivo e reprodutivo na lactação atual e na posterior de vacas holandesas / Karyne Oliveira Coelho. - - Piracicaba, 2004.

$70 \mathrm{p}$.

Dissertação (mestrado) - - Escola Superior de Agricultura Luiz de Queiroz, 2004.

Bibliografia.

1. Bovino leiteiro 2. Lactação animal 3. Leite (Produção) 4. Metabolismo animal Reprodução animal I. Título

CDD 636.234

\section{"Permitida a cópia total ou parcial deste documento, desde que citada a fonte - O autor"}




\title{
DEDICATÓRIA
}

\author{
Aos meus pais, Célia e Alcântara, a minha irmã Kamilla \\ Pelo amor, incentivo, exemplo e dedicação.
}

Como é grande o meu Amor por vocês! 


\section{AGRADECIMENTOS}

A Deus pelo dom da vida.

À Escola Superior de Agricultura Luiz de Queiroz, pela oportunidade oferecida na realização deste curso.

Ao professor Paulo Fernando Machado, pela orientação, pelo exemplo, pela confiança e pela amizade.

Ao amigo Arlei Coldebella, pelo precioso auxílio na análise estatística deste trabalho.

Aos professores Adibe Luiz Abdalla, Ivanete Susin e Paulo Henrique Mazza Rodrigues, pelas contribuições sugeridas no exame de qualificação.

Aos funcionários da Clínica do Leite/ESALQ/USP, pelo profissionalismo, pelo incentivo e pela colaboração.

À equipe da Fazenda Colorado, em especial ao proprietário Lair Antônio de Souza e aos médicos veterinários Antônio Carlos Sobreira e Sergio Soriano, que permitiram e viabilizaram a execução deste trabalho.

À amiga Paula Marques Meyer, pela amizade, alegria, cumplicidade e empenho na correção deste trabalho. 
Ao amigo Laerte Cassoli, pelos ensinamentos e amizade.

Ao amigo João Carlos Scudeller, pela amizade, alegria e apoio na montagem do banco de dados.

Aos amigos de Piracicaba, Ana Angélica Freitas Gois, Flávia Baccin Fiorante, Gilson César Kuntz Martini, Marcelo Rocha Marques, Roseli Angélica Barbosa, Liane Teresinha Wesdling Roos, Jussara da Silva Rosa, Luiz Carlos Vieira Tavares (Lucas), Lílian Barazetti e Áuria Carneiro, pela convivência e amizade.

À Família Vanzo, Vó Maria e Andréa, pelo apoio, incentivo e amizade.

A todos colegas de pós-graduação, em especial ao Carlos Corassin, Sergio Fernandes e Janice Morais, pela convivência, respeito e consideração.

Às amigas Jacqueline de Sousa, Cristine Settime Cysneiros e Daíne Vargas Couto pela amizade e incentivo.

Aos funcionários e Professores do Departamento de Zootecnia da ESALQ, pelo auxílio e presteza.

À professora Ivanete Susin, pela dedicação, profissionalismo, exemplo, amizade e aos conselhos sempre oportunos.

À secretária de pós-graduação do curso Ciência Animal e Pastagens Giovana Maria de Oliveira, pela alegria e boa vontade comigo em todos os momentos.

Aos professores, que me iniciaram na pesquisa, Ana Paula Junqueira Kipnnis, Albenones José de Mesquita, Edmar Soares Nicolau e Luiz Antônio Franco da Silva, da Escola de Veterinária da Universidade Federal de Goiás. 
Aos meus familiares, em especial à madrinha Maria do Socorro Paz Landin (Fia), pela confiança, carinho e incentivo.

Ao CNPPq, pela concessão da bolsa.

A todos, que diretamente ou indiretamente, contribuíram para realização deste trabalho...

Os meus sinceros agradecimentos!!!!! 


\section{SUMÁRIO}

\section{Página}

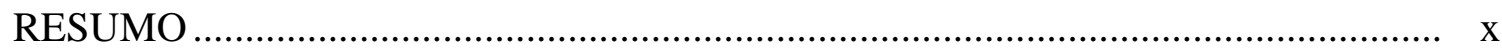

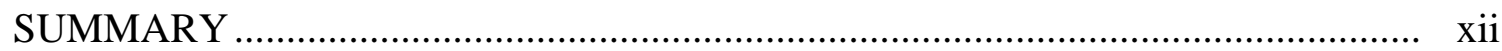

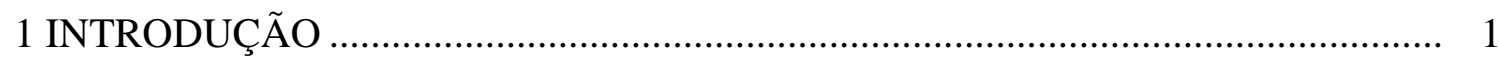

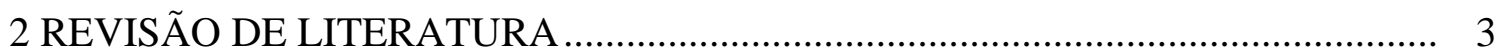

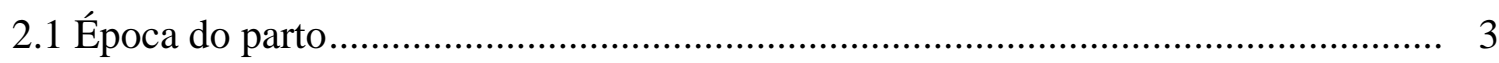

2.2 Escore de condição corporal .............................................................................. 4

2.3 Doenças do periparto...................................................................................... 6

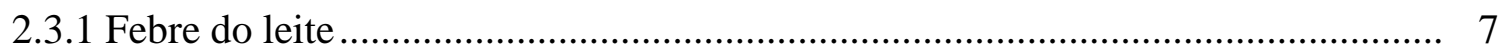

2.3.2 Retenção de placenta .......................................................................................... 9

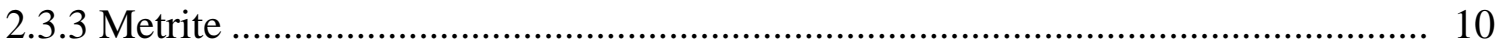

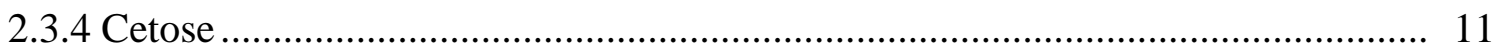

2.3.5 Deslocamento de abomaso .......................................................................... 12

2.4 Afeç̧ões de casco ……………………………………...................................... 13

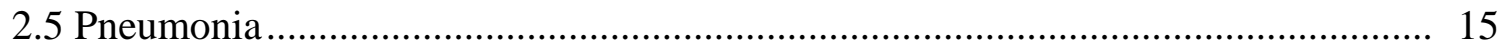

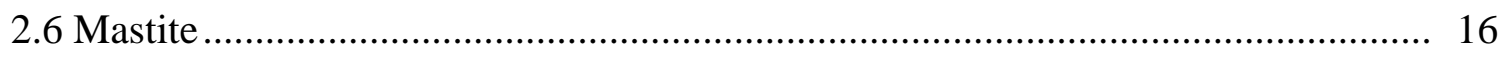

2.6.1 Células somáticas ………………............................................................... 17

2.6.2 Mastite e produção de leite................................................................................. 18

2.6.3 Mastite e reprodução .......................................................................................... 20 


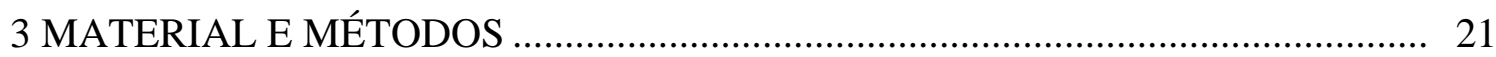

3.1 Animais e instalações .......................................................................................... 21

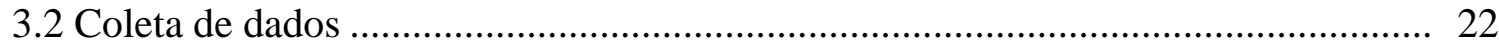

3.2.1 Produção de leite e contagem de células somáticas ............................................. 22

3.2.2 Ocorrência de enfermidades ................................................................................. 23

3.2.3 Concepção ao primeiro serviço ........................................................................... 24

3.3 Análise estatística ................................................................................................... 25

3.4 Esquema geral do trabalho ............................................................................. 26

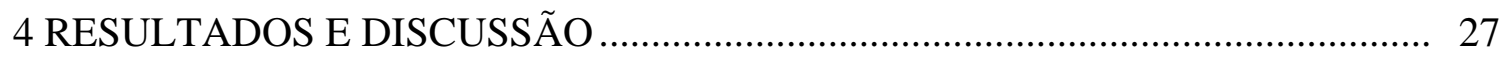

4.1 Caracterização do rebanho ................................................................................... 27

4.1.1 Análise das variáveis quantitativas ................................................................. 27

4.1.2 Freqüências qualitativas e quantitativas dos parâmetros avaliados........................ 29

4.2 Impacto dos eventos ocorridos antes e após o parto sobre a produção de leite e reprodução de vacas Holandesas da lactação atual ................................................... 31

4.2.1 Impacto dos eventos ocorridos antes e após o parto sobre a produção de leite no

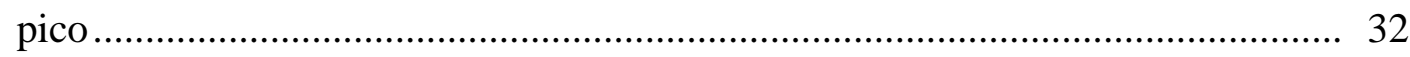

4.2.2 Impacto dos eventos ocorridos antes e após o parto sobre a produção de leite aos 305 dias

4.2.3 Impacto dos eventos ocorridos antes e após o parto sobre a concepção ao primeiro serviço

4.3 Impacto dos eventos ocorridos na lactação sobre a produção de leite e reprodução da lactação posterior.

4.3.1 Impacto dos eventos ocorridos na lactação sobre a produção de leite no pico da lactação posterior

4.3.2 Impacto dos eventos ocorridos na lactação sobre a produção de leite aos 305 dias da lactação posterior

4.3.3 Impacto dos eventos ocorridos na lactação sobre a concepção ao primeiro serviço da lactação posterior 


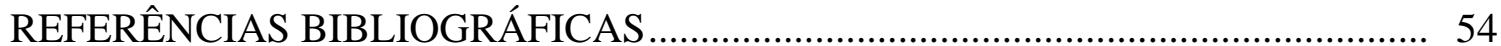




\title{
IMPACTO DOS EVENTOS OCORRIDOS ANTES E APÓS O PARTO SOBRE O DESEMPENHO PRODUTIVO E REPRODUTIVO NA LACTAÇÃO ATUAL E NA POSTERIOR DE VACAS HOLANDESAS
}

\author{
Autora: KARYNE OLIVEIRA COELHO \\ Orientador: Prof. Dr. PAULO FERNANDO MACHADO
}

\section{RESUMO}

Com o objetivo de investigar o impacto dos eventos ocorridos antes e após o parto sobre a produção de leite no pico, produção de leite na lactação (305 dias) e concepção ao primeiro serviço na lactação atual e na lactação posterior, foram coletados dados zootécnicos e sanitários de 2.084 lactações, provenientes de 665 vacas da raça Holandesa, de um rebanho comercial do estado de São Paulo. Os escores de condição corporal (na secagem e ao parto), a época do parto, o número de dias do período seco, a ocorrência de doenças, as produções de leite (no pico e na lactação) e a concepção ao primeiro serviço foram registradas. A análise estatística foi realizada por meio de regressão múltipla e logística. Os resultados obtidos demonstraram que a época do parto (verão), a duração do período seco, o escore de condição corporal à secagem, o logaritmo natural da primeira contagem de células somáticas após o parto, a ocorrência de retenção de placenta e o deslocamento de abomaso afetaram negativamente a produção de leite no pico da lactação atual, com efeitos distintos em função da ordem de lactação. Os mesmos eventos, incluindo a ocorrência de mastite clínica até os 60 dias pós-parto, afetaram negativamente a produção de leite aos 305 dias da lactação atual. 
Quanto à concepção ao primeiro serviço da lactação atual, os resultados obtidos revelaram que a ordem de lactação, a época do parto (verão) e o escore de condição corporal ao parto afetaram negativamente a concepção, com efeitos diferentes em função da ordem de lactação. Quanto à lactação posterior, os principais eventos que afetaram a produção de leite no pico foram: a época do parto (verão), o escore de condição corporal à secagem, o logaritmo natural da primeira contagem de células somáticas, a ocorrência de mastite clínica, o número de casos de mastite sub-clínica durante a lactação e a cetose. Enquanto para a produção de leite aos 305 dias da lactação posterior, os principais fatores que afetaram foram: o escore de condição corporal à secagem, a ocorrência de cetose e a mastite clínica. Em relação à concepção ao primeiro serviço da lactação posterior, os principais eventos que afetaram tal variável foram: o escore de condição corporal à secagem, o número de casos de mastite sub-clínica durante a lactação, a ocorrência de pneumonia e o deslocamento de abomaso. Contudo, o coeficiente de determinação $\left(\mathrm{R}^{2}\right)$ para os eventos responsáveis por alterações na produção de leite no pico $\left(\mathrm{R}^{2}=0,08\right)$, produção de leite aos 305 dias $\left(\mathrm{R}^{2}=0,06\right)$ e concepção ao primeiro serviço $\left(\mathrm{R}^{2}=0,008\right)$ da lactação posterior foi baixo. 


\title{
IMPACT OF THE EVENTS OCCURRED PRE AND POSTPARTUM ON PRODUCTIVE AND REPRODUCTIVE PERFORMANCE IN THE CURRENT AND SUBSEQUENT LACTATION OF HOLSTEIN COWS
}

\author{
Author: KARYNE OLIVEIRA COELHO \\ Adviser: Prof. Dr. PAULO FERNANDO MACHADO
}

\section{SUMMARY}

The objective of this study was to investigate the impact of events occurred pre and postpartum upon milk production at peak, milk production during lactation (305 days) and conception at first service in the current and subsequent lactation of dairy cows. Data related to production and sanity of 2,084 lactations were collected from 665 Holstein cows of a commercial herd from Sao Paulo state. Body condition scores (at drying off and at calving), calving season, dry period length, occurrence of diseases, milk productions (at peak and during lactation) and conception at first service were registered. Statistical analysis was accomplished using multiple and logistic regression. Results showed that calving season (summer), dry period length, body condition score at drying off, natural logarithm of the first somatic cells count (SCC) after calving, occurrence of retained placenta and displacement of abomasum affected negatively milk production at peak in the current lactation, with different effects in function of lactation order. The same events, including the occurrence of clinical mastitis until 60 days post-calving, affected negatively milk production during the current lactation (305 days). Relating to conception at first service in the current 
lactation, results showed that lactation order, calving season (summer) and body condition score at calving affected negatively the conception, with different effects due to lactation order. Regarding the subsequent lactation, the main events that affected milk production at peak were: calving season (summer), body condition score at drying off, natural logarithm of the first SCC, occurrence of clinical mastitis, number of cases of sub-clinical mastitis during lactation and ketosis. The main factors that affected milk production of the subsequent lactation (305 days) were: body condition score at drying off, occurrence of ketosis and clinical mastitis. In relation to conception at first service in the subsequent lactation, the events that influenced it were: body condition score at drying off, number of cases of sub-clinical mastitis during lactation, occurrence of pneumonia and displacement of abomasum. However, determination coefficients $\left(\mathrm{R}^{2}\right)$ of the events responsible for impacts on milk production at peak $\left(\mathrm{R}^{2}=0.08\right)$, milk production during lactation (305 days) $\left(\mathrm{R}^{2}=0.06\right)$ and conception at first service $\left(\mathrm{R}^{2}=0.008\right)$ of the subsequent lactation were low. 


\section{INTRODUÇÃO}

A análise do setor leiteiro do país indica que a produtividade continua baixa, com uso de técnicas de produção rudimentares e rendimento econômico questionável. Apesar desse panorama, é notório que estão ocorrendo melhorias caracterizadas pelo uso de pastagens adubadas, introdução de animais especializados criados em confinamento e uso de técnicas de melhoramento genético, entre outras.

Mesmo com as recentes inovações, a produção de leite no Brasil ainda é muito aquém das necessidades. O país importa cerca de 2 bilhões de litros de leite por ano, o que equivale a mais de 10\%, considerando os 21 bilhões de litros produzidos em 2002 (Anualpec, 2003). Esses dados refletem a baixa capacitação dos produtores de leite e a desorganização do setor lácteo que, apesar de terem buscado a introdução de novos métodos de criação, não se preocuparam com o bem-estar animal, provocando maior incidência de enfermidades e, conseqüentemente, diminuição da produção de leite e da eficiência reprodutiva dos rebanhos.

Nesse contexto, alguns trabalhos vêm sendo realizados com a finalidade de identificar os principais pontos críticos, considerando a produtividade dos rebanhos leiteiros, baseados em indicadores, tais como, produção de leite e taxa de concepção. Mas, geralmente, esses estudos se preocupam apenas com a lactação atual, não extrapolando para a vida produtiva do animal nas próximas lactações. Nesses trabalhos, a inadequada nutrição (Ruegg \& Milton 1995), o estresse térmico (Gasparino, 1996), a ocorrência de enfermidades infecciosas e/ou metabólicas (Rajala-Schultz \& Grohn, 1999; Ramos, 1999; Fleisher et al., 2001; Bueno et al., 2002; Cardoso et al., 2002) têm sido associados à queda de produção. 
Considerando a nutrição, monitorada pela avaliação da condição corporal, Ruegg \& Milton (1995) destacam que as mudanças no escore de condição corporal entre o final da gestação, parto e início da lactação têm sido responsabilizadas pelo baixo desempenho produtivo e reprodutivo, além de aumentar a incidência de distúrbios metabólicos. A época do parto também influencia a magnitude de produção e reprodução dos rebanhos, isso devido ao estresse térmico, especialmente em países de clima tropical, como o Brasil (Gasparino, 1996).

Entre os fatores citados, a ocorrência de doenças, tais como, mastite, enfermidades do casco, pneumonias e doenças do periparto (cetose, acidose, febre do leite, deslocamento de abomaso, metrite e retenção de placenta) tem merecido grande atenção, primeiramente devido à significativa incidência, principalmente em rebanhos confinados. Outro fator é a etiopatogenia de ação dessas enfermidades que, muitas vezes, afetam diretamente a função produtiva e reprodutiva dos rebanhos.

Entretanto, quanto à importância dos eventos ocorridos em uma lactação e seus respectivos impactos sobre a próxima lactação, há poucos trabalhos publicados. Considerando apenas as perdas referentes à produção de leite, Lucey \& Rowlands (1984) e Block (1984) relatam a influência da ocorrência de doenças na lactação sobre a produção de leite da próxima lactação. Porém, Geishauser et al. (1998) não observaram efeito do deslocamento de abomaso na lactação sobre a produção de leite da lactação subseqüente. Quanto à eficiência reprodutiva, não há trabalhos que enfoquem tal relação, mas acredita-se que exista.

Portanto os objetivos desta dissertação foram:

1) Verificar o impacto dos eventos ocorridos antes e após o parto sobre a produção de leite no pico, produção de leite aos 305 dias e concepção ao primeiro serviço da lactação atual.

2) Verificar o impacto dos eventos ocorridos na lactação sobre a produção de leite no pico, produção de leite aos 305 dias e concepção ao primeiro serviço da lactação posterior. 


\section{REVISÃO DE LITERATURA}

\section{1 Época do parto}

As variações climáticas, que ocorrem durante o ano, podem afetar diretamente a produção de leite e a reprodução, devido aos fatores, tais como, temperatura, umidade, precipitação, magnitude do foto-período e, indiretamente, pela disponibilidade e qualidade das plantas forrageiras (Galvão, 1993).

No entanto, considerando os fatores citados anteriormente, o estresse térmico constitui um dos principais itens que podem afetar a produção de leite e a reprodução. O estresse térmico ocorre quando a carga calórica do animal é maior do que sua capacidade de dissipação de calor (Pursley et al.,1998). A temperatura confortável (zona de conforto térmico) para os bovinos leiteiros está entre 5 e $25^{\circ} \mathrm{C}$ (Gasparino, 1996).

Com o aumento da temperatura ambiente, o hipotálamo responde induzindo o animal a uma série de adaptações fisiológicas: aumento do fluxo sangüíneo periférico (diminuindo a absorção de nutrientes), transpiração e polipnéia, fatores esses que diminuem o consumo de alimento. Alterações hormonais também são observadas; ocorre redução dos hormônios metabólicos e antidiurético associados ao aumento da aldosterona e dos hormônios epinenefrina e norepinefrina, que quando elevado por longos períodos causam imunossupressão (Collier, 1982).

A temperatura elevada pode causar queda na produção de leite, redução da taxa de concepção, aumento do intervalo entre partos e aumento da incidência de doenças, entre as quais, mastites, problemas de casco, pneumonias e retenção de placenta (Blood \& Radostitis, 1987). 
Considerando apenas a produção de leite, as perdas são significativas quando o parto acontece no verão. Vários trabalhos realizados no Brasil ressaltam a diminuição da produção de leite (Nobre et al., 1984; Galvão, 1993; Barbosa, 1995; Gasparino, 1996). Milagres et al. (1988), estudando o impacto da estação ao parto sobre as características produtivas de vacas mestiças holandesas, observaram que as maiores produções foram das vacas que pariram no início do outono-inverno.

Fuquay (1981) relata que animais, sob estresse calórico, diminuem a produção de leite, o consumo de alimentos e a atividade física e, conseqüentemente, a capacidade reprodutiva. Faust et al. (1988), Silva et al. (1992) e Farin et al. (1994) observaram que o estresse térmico reduziu significativamente as taxas de prenhez em vacas leiteiras.

Bandinga et al. (1984) observaram que em rebanhos da Florida a taxa de concepção para animais que pariram no inverno foi de $50 \%$ e de apenas $10 \%$ para os que pariram no verão. Silva et al. (1992) relataram menores taxas de concepção, com o aumento de dias para a $1^{\text {a }}$ cobertura e menor concepção na inseminação artificial, quando os animais pariram ou foram cobertos no verão. Pursley et al. (1998) mostraram significativa mortalidade embrionária devido ao estresse calórico. No entanto, Thatcher \& Colier (1986) descrevem que as taxas de concepção de novilhas não se alteram em função da estação do ano.

\subsection{Escore de condição corporal}

O escore de condição corporal (ECC) trata-se de uma ferramenta de manejo utilizada para avaliar as reservas energéticas da vaca. É baseada na observação visual e palpação de áreas específicas, com a finalidade de avaliar os depósitos de tecido adiposo e massa muscular (Edmonson et al.,1989; Lago et al., 2001).

O ECC pode variar em função do modelo adotado; no entanto, valores altos indicam animais com maior reserva corporal. Wildman et al. (1982) propuseram uma escala de 1 (extremamente magro) a 5 (gordo) com intervalo de 0,25 ponto para aferir o ECC. Também pode-se utilizar de sub-escalas de 0,5 ponto. O monitoramento 
do escore deve ser feito sempre pela mesma pessoa, uma vez que os valores atribuídos são subjetivos (Lago et al., 2001).

A determinação do ECC é recomendada no momento da secagem, ao parto, no pico da lactação e no momento da cobertura (Fergusson 1994). Os valores recomendados são de 3,0 a 4,0, desde a secagem ao parto, de 2,5 a 3,0 até os dois meses de lactação e de 2,5 a 3,5 pontos, após a $3^{\circ}$ mês de lactação (Wildman et al., 1982).

Pesquisas nessa área têm mostrado que a condição corporal influencia a produtividade, a reprodução, a saúde e a longevidade dos animais. Exemplificando: vacas muito gordas são mais susceptíveis a problemas metabólicos, infecções e partos distócicos, o que reflete na produção leite (Garnsworthy, 1988; Gearhart et al., 1990; Ruegg et al.,1992; Fergusson et al., 1994).

Vacas muito magras freqüentemente apresentam menor produção e concentração de gordura no leite, devido à pequena reserva de energia e proteína (Fergusson et al., 1994). No entanto, Gearhart et al. (1990) ressaltam que vacas magras conseguem aumentar a ingestão de matéria seca mais rapidamente, alcançando o balanço energético positivo mais cedo do que vacas gordas. Entretanto, vários pesquisadores não encontraram associação entre escore de condição corporal e produção de leite (Ruegg \& Milton, 1995; Santos, 1996; Lago et al., 2001).

Considerando o desempenho reprodutivo, a severidade do balanço energético negativo no início da lactação pode influenciar, especialmente, a concepção. Portanto, o ECC pode consistir em uma excelente ferramenta para o manejo reprodutivo (Edmonson et al., 1989; Gearhart et al.,1990 e Nebel \& McGilliard, 1993).

Humprey et al. (1983) mostraram que a hipoglicemia aguda após o parto, em vacas, alteram o padrão de secreção do hormônio luteinizante (LH), por meio do bloqueio do aumento da amplitude dos pulsos, sugerindo um mecanismo pelo qual nutrição e reprodução podem estar interelacionados. Short \& Adams (1988), estudando vacas que apresentaram anestro pós-parto, observaram que os animais com baixo ECC possuíam baixa concentração de glicose (hipoglicemia), influenciando diretamente a reprodução das vacas. A glicose é a única fonte de energia utilizada pelo sistema nervoso e, considerando que o sistema neuroendócrino está intimamente envolvido no 
controle reprodutivo e na secreção hormonal, parece que a concentração de glicose seja o mediador específico para os efeitos sobre a reprodução.

No entanto, Ruegg \& Milton (1995) relataram que o ECC ao parto parece não ter relação com concepção ou com número de serviços por concepção. Porém, Fulkerson (1984), Butler \& Smith (1989) e Santos (1996) concluíram que a boa condição corporal ao parto foi um fator importante para a retomada da atividade cíclica após o parto. Patton et al. (1988) relatam que animais que tiveram maior ECC ao parto apresentaram menor intervalo entre partos. Ferguson (1992), agrupando vacas de acordo com perdas de ECC, mostrou que vacas que perderam de 0,5 a 1,0 ponto de ECC tiveram taxa de concepção de 53\% e as que perderam mais que 1,0 ponto de ECC entre o parto e a cobertura tiveram taxa de $17 \%$. Portanto, a baixa condição corporal tem efeito inibitório sobre a atividade ovariana (Randel,1990).

Esses diferentes resultados obtidos podem ser devido aos diferentes métodos adotados para avaliação do ECC e às diferenças de manejo, alimentação e produção entre os rebanhos estudados (Lago et al., 2001).

\subsection{Doenças do periparto}

A tecnificação da pecuária leiteira encontra-se associada à ocorrência de um complexo de enfermidades do periparto. As vacas leiteiras, especialmente as de alta produção, são mais susceptíveis às doenças, principalmente as metabólicas (Fleisher et al., 2001). Esses fatores, aliados às intensas transformações hormonais e metabólicas do período de transição, aumentam a incidência de distúrbios (Risco, 1992). Entre as doenças de maior ocorrência nessa fase, destacam-se febre do leite, cetose, metrite, deslocamento de abomaso e retenção de placenta.

Vários trabalhos têm enfocado um significativo aumento da incidência de doenças do periparto em rebanhos leiteiros, principalmente em criações intensivas e de grande produção de leite (Guard, 1996; Guard, 2000; Fleisher et al., 2001). A incidência média desses distúrbios está apresentada na Tabela 1. 
Tabela 1. Incidência de doenças no pós-parto, em rebanhos de alta produção de leite

\begin{tabular}{ll}
\hline Enfermidades & Incidência \\
\hline Febre do leite & $0,7-2,3$ \\
Deslocamento de abomaso & $0,9-2,5$ \\
Cetose & $29,3-35,3$ \\
Retenção de placenta & $15,1-23,3$ \\
Metrite & $24,3-35,3$ \\
\hline
\end{tabular}

Fonte: Markusfeld (1990) e Risco (1992).

A ocorrência dessas doenças está associada a significativos prejuízos na atividade leiteira, mas geralmente o produtor não percebe o impacto negativo até que se tornem evidentes, com apresentação de vários casos clínicos (Markusfeld,1990; Guard, 1996). No entanto, as perdas iniciam-se logo que uma vaca recém-parida desenvolve um problema sub-clínico, persistindo até que seja diagnosticado.

Os prejuízos ocasionados pela ocorrência de doenças do periparto estão relacionados aos gastos com medicamentos, assistência veterinária, diminuição da produção de leite e problemas reprodutivos, dentre outros (Guard, 1996). Pesquisas realizadas em Cornell (EUA) destacam que animais acometidos por distúrbios metabólicos perdem o equivalente a $\mathrm{R} \$ 520,00$, apenas nos primeiros 30 dias da lactação, considerando apenas a redução da produção de leite (Guard, 2000). Holcomb et al. (2001) destacam que a ocorrência dessas enfermidades pode diminuir o pico de produção de leite em 5 a $10 \mathrm{~kg}$ de leite ao dia, totalizando 1.000 a $2.000 \mathrm{~kg}$ de leite a menos na lactação. Mas, infelizmente, os prejuízos não param por aí, pois as doenças afetam também os índices reprodutivos e a taxa de descarte do plantel.

\subsubsection{Febre do leite}

A febre do leite é uma doença metabólica que ocorre mais comumente em fêmeas adultas ao parto, sendo os animais de alta produção de leite os mais susceptíveis (Rebhun, 2000; Fleisher et al., 2001). Acontece, geralmente, até 72h após o parto, podendo afetar até 65\% das vacas multíparas (Pires, 1993).

A enfermidade caracteriza-se por declínio nas concentrações de cálcio do plasma, logo após o parto, devido ao aumento súbito das necessidades desse mineral em 
ocasião do aumento da produção de leite e formação do colostro. Portanto, alguns animais não conseguem mobilizar o necessário para suprir as necessidades, desencadeando a febre do leite (Curtis et al., 1985; Pires, 1993). No entanto, ressalta-se que a febre do leite não ocorre devido à deficiência de cálcio, mas, essencialmente, ao aumento da intensidade e duração da hipocalcemia fisiológica que, geralmente, a vaca leiteira de alta produção sofre ao parto (Goff \& Horst, 1995).

Vários fatores podem contribuir para a ocorrência do distúrbio, entre eles, as raças sendo algumas mais susceptíveis, tais como Jersey, Channel Island, Swedish vermelho e branco. Goff \& Horst (1995) relatam que vacas da raça Jersey possuem menos receptores intestinais para absorção do cálcio do que as Holandesas. A idade aumenta a chance de ocorrência, devido ao aumento da produção de leite associado à redução da habilidade de mobilização do cálcio das reservas ósseas, à redução no transporte ativo de cálcio no intestino e ao balanço entre cálcio e fosfóro na dieta, principalmente para as vacas no período do pré-parto (Horst et al., 1990).

Há três estágios clínicos discerníveis da febre do leite. No primeiro estágio, os animais apresentam sinais de excitabilidade e irritabilidade. No segundo, os animais apresentam sinais de anorexia, hipotermia e taquicardia, podendo evoluir para flacidez completa, coma e, finalmente, morte no terceiro estágio (Block, 1984). O tratamento com cálcio, no estágio inicial, é efetivo e cerca de $70 \%$ das vacas nãotratadas morrem dentro de dois dias após a manifestação dos sintomas (Hibbs, 1950 citado por Blood \& Radostitis, 1987).

Os principais prejuízos associados à ocorrência de febre do leite devem-se à redução da vida produtiva dos animais, gastos com tratamentos, descartes prematuros, diminuição da produção de leite e dos índices reprodutivos e, eventualmente, morte (Guard, 1996; Rebhun, 2000). Há maior susceptibilidade a problemas sanitários secundários (principalmente metrites e mastites) devido, principalmente, à elevada concentração de cortisol no plasma, que deprime a resposta imunológica do animal (Curtis et al., 1984).

Nos EUA, cada caso de febre do leite custa, em média, US\$334 (Rebhun, 2000) considerando apenas a diminuição da produção de leite. Block (1984) relata que 
os animais com febre do leite, recuperados por tratamentos oportunos, produzem $5-10 \%$ menos de leite na lactação.

\subsubsection{Retenção de placenta}

A retenção de placenta, também denominada de retenção de membranas fetais, caracteriza-se pela não expulsão das membranas fetais em até 18 horas após o parto. Porém existem divergências nas informações (em relação ao tempo) encontradas na literatura (Fernandes et al., 1999). Geralmente, ocorre quando fatores associados ao estresse, fatores imunológicos e nutricionais impedem a separação entre a carúncula e cotilédone (Rajala-Schultz \& Grohn, 1998). Partos anormais, doenças infecciosas, deficiências nutricionais e doenças metabólicas ao parto podem aumentar a incidência da doença (Joosten et al., 1987).

Os sinais clínicos são óbvios, quando as membranas fetais protraem a partir da vulva ou ficam penduradas ventralmente da vulva à marca da anca, ao úbere traseiro ou jarrete. As afecções são menos aparentes quando se retêm membranas dentro do útero ou se essas se projetam no interior da cervix ou da vagina e necessitam de um exame vaginal para serem detectadas (Blood \& Radostitis, 1987; Rebhun, 2000).

Os principais prejuízos, associados à ocorrência de retenção de placenta, são: redução da fertilidade, descarte prematuro de animais, morte (a taxa de mortalidade resultante dessa patologia está em torno de 4\%), descarte de leite e diminuição da

produção de leite (Rowlands \& Lucey, 1986; Rajala-Schultz \& Grohn, 1998). O custo estimado, considerando apenas o tratamento e a diminuição da produção de leite, é de US\$285 por animal (Guard, 1996).

Van Werven et al. (1992) relatam diminuição da produção de leite em vacas acometidas por retenção de placenta. Porém, Martin et al. (1986) não observaram efeito sobre a produção de leite aos 305 dias, associada à ocorrência da doença.

Os efeitos sobre os índices reprodutivos decorrem de duas situações principais: retardo da involução uterina e maior chance de contaminação do útero. Ambas condições são procedentes da permanência dos anexos fetais além do tempo 
normal. Dessa maneira, ocorre progressiva putrefação e processo de liquefação, predispondo a contaminações, principalmente as bacterianas. Esses fatores associados diminuem a atividade do miométrio, em conseqüência, levam à inércia uterina (Rebhun, 2000).

Segundo Joosten \& Hensen (1987), esse quadro retarda a involução do útero, que é imprescindível para o restabelecimento dos ciclos estrais. Outro fator agravante é a diminuição do mecanismo de defesa uterina, principalmente a fagocitose, o que aumenta a chance de doenças secundárias, principalmente metrite. Coleman et al. (1985), ao estudarem dados de 7.596 vacas, relatam baixa eficiência reprodutiva em animais que apresentaram retenção de placenta.

\subsubsection{Metrite}

A metrite pós-parturiente é extremamente comum nos bovinos leiteiros (Bigras-Poulin et al., 1990). Metrite é um termo geral, utilizado para denominar as infecções uterinas do pós-parto do endométrio e das camadas mais profundas que podem ou não causar sinais septicêmicos, podendo ter implicações no desempenho reprodutivo dos animais acometidos (Markusfeld \& Ezra, 1993; Rebhun, 2000).

Vários agentes podem estar envolvidos na infecção, tais como bactérias, fungos, vírus e protozoários (Rebhun, 2000). Nessa fase, o trato reprodutivo está susceptível, especialmente em casos de traumas ou lesões na vagina e/ou vulva ou em casos de imunossupressão. Segundo Blood \& Radostits (1987), a metrite pode ocorrer em 80\% das vacas com retenção de placenta. Além desse fator, Curtis et al. (1984) e Josten \& Hensen (1987) consideram que partos sujos e distócicos, atonia uterina, contaminação iatrogênica vaginal e cetose aumentam a ocorrência de metrite.

Os sintomas apresentados pelos animais enfermos são: presença de descarga vaginal purulenta, odor e alterações nas paredes do útero (Rowlands \& Lucey, 1986; Simerl et al., 1992). O diagnóstico é baseado na história clínica, nas alterações físicas, em exames complementares como radiografia e/ou ultrassonografia para avaliar o tamanho e o conteúdo do útero e citologia vaginal (Rebhun, 2000). 
Os principais prejuízos associados à ocorrência de metrite são: redução da eficiência reprodutiva de vacas leiteiras, descarte prematuro de animais, descarte e diminuição da produção de leite e morte (Lucey et al., 1986; Rowlands \& Lucey, 1986). A redução da produção de leite pode chegar a 3,8\%, sendo que o maior impacto ocorre nos primeiros 30 dias de ocorrência da doença.

Van Werven et al. (1992) e Simerl et al. (1992) relatam diminuição da produção de leite, em vacas acometidas por metrite. No entanto, Martin et al. (1986) não observaram efeito sobre a produção de leite aos 305 dias, associada à ocorrência da doença. Rajala-Schultz \& Grohn (1998) também relatam que a ocorrência de metrite, logo no início da lactação, não afeta a produção de leite.

\subsubsection{Cetose}

Cetose é uma doença metabólica que acomete vacas leiteiras de alta produção, caracterizando-se por queda na concentração de glicose e aumento excessivo dos corpos cetônicos no sangue (Fleisher et al., 2001), podendo ocorrer na forma clínica ou subclínica (Lean et al., 2001).

No início da lactação, a vaca passa por um processo de elevada demanda de energia, em decorrência do aumento da produção de leite. Entretanto, o consumo de alimento pelo animal não acompanha tal exigência, entrando num balanço energético negativo. Com isso, ocorre aumento da mobilização de gordura pelo organismo, a fim de suprir as necessidades energéticas do animal. Em conseqüência, a produção de corpos cetônicos torna-se intensa, acima da capacidade de utilização pelo organismo, gerando o seu acúmulo, desenvolvendo-se o quadro clínico ou sub-clínico de cetose (Guard, 2000).

Dentre os sinais clínicos apresentados pelos animais acometidos, destacase: diminuição da produção leiteira, sinais de hipofagia, perda de peso, sinais nervosos, hálito cetótico característico, hipoglicemia, hipoinsulinemia, acetonemia, letargia podendo evoluir para morte (Rebhun, 2000).

As principais perdas, associadas à ocorrência de cetose, são: redução de fertilidade (Butler \& Smith, 1989; Andersson \& Gustafsson, 1991; Emanuelson \& 
Oltenacu, 1998), aumento do risco da ocorrência de metrites, cistos ovarianos (Dohoo \& Martin, 1984; Kuzma \& Roman, 1994) e diminuição da produção de leite (Guard, 2000).

Schlatter (1997) calcula diminuição da produção em ordem de 200 kg por lactação, devido apenas à forma clínica. A alta concentração de corpos cetônicos no sangue também tem sido relacionada à redução de fertilidade, devido ao efeito negativo sobre o hormônio liberador de gonadotrofina hipotalâmica (GnRH) (Butler \& Smith, 1989). Fergusson et al. (1994) relatam que vacas com cetose apresentam longo intervalo para que ocorra a primeira ovulação, além de decréscimo da fertilidade, resultados esses confirmados por Gonzáles \& Campos (2003).

Mienttinem \& Setala (1993) observaram que o aumento de corpos cetônicos no leite está associado à diminuição da produção de 1 a 1,4 kg de leite/dia e a perdas totais de $233 \mathrm{~kg}$ de leite nos primeiros 100 dias. Fleisher et al. (2001) observaram que a ocorrência de doenças do periparto, entre essas a cetose, é mais incidente em animais de maior produtividade.

\subsubsection{Deslocamento de abomaso}

O deslocamento de abomaso (DA) acomete principalmente vacas de alta produção leiteira (Blood \& Radostits, 1987). Incide com maior freqüência até a $6^{\text {a }}$ semana após o parto, podendo ocorrer tanto para o lado direito como para o esquerdo. No entanto, 90\% dos casos são para o esquerdo (Rebhun, 2000).

O deslocamento de abomaso trata-se de uma doença de caráter multifatorial. Os principais fatores de risco são: raça, sexo, idade, parto, época do parto e nutrição (Markusfeld, 1990). O risco de deslocamento de abomaso também está presente em decorrência de distocias, gestação gemelar, retenção de placenta, metrite, cetose e hipocalcemia (Curtis et al., 1985; Geishauser, 1998).

A sintomatologia clínica, apresentada pelos animais acometidos pelo deslocamento de abomaso, inclui perda do apetite, queda na produção de leite em torno de 30 a 50\%, assimetria da silhueta, timpanismo ruminal e desidratação. Ao exame clínico, a temperatura, as freqüências cardíacas e respiratórias permanecem normais. A 
auscultação e a percussão simultâneas revelam uma área de ressonância timpânica (Blood \& Radostits, 1987; Rebuhn, 2000).

Os principais prejuízos associados à ocorrência do deslocamento de abomaso são: diminuição da produção de leite, tratamento, assistência veterinária, descarte prematuro de animais e baixo índice reprodutivo (Eicker, 1995). Além desses fatores, animais com DA possuem atividade fagocitária diminuída, tornando-se suscetíveis ao aparecimento de doenças infecciosas (Detilleux et al., 1990).

Raizman \& Santos (2002), estudando o impacto da ocorrência do DA sobre os aspectos produtivos e reprodutivos de vacas leiteiras, relatam diminuição da produção de leite na lactação em torno de 4,7\%. Entretanto, quanto aos aspectos reprodutivos, os autores não encontraram efeito. Detilleux et al. (1990) mostraram que as perdas podem representar até 30\% na produção de leite na lactação. No entanto, os autores afirmam que quando o diagnóstico e o tratamento do DA são realizados adequadamente, as perdas são insignificantes .

Pesquisas realizadas em 20 fazendas do Canadá apontam que o deslocamento de abomaso foi um dos principais fatores responsáveis por descarte e que a produção de leite dos animais que permaneceram no rebanho decresceu cerca de 30\%, no entanto não afetou a produção na lactação subseqüente. Os mesmos autores destacam que quando a correção cirúrgica é rápida e eficiente, os animais, em no máximo 120 dias, recuperam a atividade produtiva (Shearer \& Van Horn, 1998).

\subsection{Afecções de casco}

Entre as principais afecções de casco que acometem os bovinos, destacam-se: a dermatite digital, a pododermatite necrosante, o flegmão interdigital, a pododermatite asséptica difusa ou laminite, a pododermatite circuscrita ou úlcera de sola, as erosões, entre outras (Silva, 1997; Ramos, 1999; Ramos et al., 2001).

Vários fatores podem estar envolvidos na etiologia das afecções de casco, entre os quais: predisposição genética, meio ambiente, manejo, estação do ano e nutrição. Agentes bacterianos, tais como, Fusobacterium necrophorum, Dichelobacter 
nodosus e espiroquetas também têm sido, constantemente, relacionados à ocorrência de afecções de casco (Greenough 1986; Nocek, 1993; Silva et al., 2002). Algumas lesões de casco podem ser secundárias às laminites, que são mais freqüentes no período de transição (Ramos et al., 2001).

Os animais acometidos pelas afecções podais apresentam sintomas gerais de claudicação e dor (Ramos et al., 2001). Os movimentos tornam-se rígidos e o animal se locomove com dificuldade, fica arqueado, na tentativa de redistribuir seu peso e aliviar a pressão sobre o membro afetado (Nocek, 1997; Moraes, 2000). Entre os sintomas específicos, destaca-se sinal de inflamação, sensibilidade nos cascos e ao redor da banda coronária, a parede dos cascos é freqüentemente sensível à pressão e o casco pode-se apresentar ligeiramente levantado, comprido e côncavo (Ramos et al., 2001). Muitas vezes esses sinais passam despercebidos e, no momento que são identificados, as lesões já são irreversíveis.

A incidência de afecções de casco em bovinos pode estar associada aos sistemas de manejo, ao ambiente e à raça (Nocek, 1993). As raças taurinas, especialmente a holandesa, são mais sensíveis do que as zebuínas. Quanto ao sistema de produção, observa-se que nas criações intensivas, a incidência de doença digital geralmente é alta, com maior prevalência de laminite, pododermatite circunscrita e dermatite digital (Borges et al., 1992; Borges, 1998).

A freqüência média de enfermidades de casco varia entre 5 a 30\%; em casos extremos pode alcançar índices de 50\% (Nocek, 1997), enquanto Witaker et al. (1983) citam incidência de 17 a 25\%. No Brasil, vários trabalhos relatam alta incidência das afecções de casco. Silva et al. (1992) observaram índices de 11,1\% em rebanhos criados a pasto e 14,2\% em rebanhos confinados. Por sua vez, Molina et al. (1999), ao estudarem 469 animais da bacia leiteira da região de Belo Horizonte, encontraram incidência de 30,3\%.

As principais perdas econômicas associadas a ocorrências de afecções de casco referem-se à redução da vida útil dos animais, diminuição da produção de leite (principalmente persistência), perda de peso, redução da fertilidade, alto custo dos tratamentos (medicamentos e veterinário) que somam, em média, R\$133,29 por animal 
(Ramos et al., 2001), além das alterações de manejo que são introduzidas para tratarem esses animais (Groehn \& Kaneene, 1992; Dirksen, 1993; Coelho et al., 2001; Coelho et al., 2003).

Para Peeler et al. (1994), a inapetência apresentada pelos animais enfermos pode levar ao anestro. Sheldon (1997) ressalta que o fator de estresse associado à ocorrência das doenças distais é o fator determinante na redução da taxa de fertilidade e prenhez de um rebanho.

Collick et al. (1989) notaram diminuição da fertilidade em animais enfermos e relatam que muitas questões são inexplicáveis. No entanto, Dobson \& Alan (1987) encontraram alta correlação entre baixa condição corporal e afecção de casco em bovinos e ressaltam que a inibição da secreção de LH (hormônio luteinizante) pode influenciar o mecanismo de retroalimentação positiva do estradiol e em, conseqüência, diminuir a fertilidade.

Em relação à produção de leite, Ramos et al. (2001) relatam diminuição da produção em vacas leiteiras. No entanto, Coelho et al. (2003) observaram diminuição da produção de leite apenas no pico da lactação posterior para vacas acometidas por afecções de casco na lactação anterior.

\subsection{Pneumonia}

O sistema respiratório dos bovinos, principalmente dos leiteiros, está constantemente exposto a uma variedade de microrganismos potencialmente patogênicos; porém, na maioria das vezes, os animais permanecem saudáveis devido às defesas pulmonares. Quando o animal está com sistema imune debilitado, ou o tecido pulmonar sofre alguma lesão, vários agentes podem se estabelecer e iniciar um processo de caráter infeccioso (Cardoso et al., 2002). Dentre os patógenos, as bactérias constituem uma das principais causas de pneumonias e, conseqüentemente, são tidas como responsáveis por significativas perdas econômicas (Mosier et al., 1997).

A pneumonia é uma doença infecciosa emergente que acomete principalmente animais jovens, especialmente os criados em sistemas intensivos. Mas 
podem incidir em animais adultos, principalmente os leiteiros. Bactérias do gênero Mycoplasma, Pasteurela e Ureaplasma e os vírus sincial respiratório, parainfluenza e herpesvírus bovino do tipo I são os principais agentes isolados e, freqüentemente, agem em sinergismo (Rebhun, 2000; Cardoso et al., 2002)

Os principais sinais apresentados pelos animais acometidos pela doença são: tosse produtiva, polipnéia, anorexia, rápida perda de peso e prostração (Mosier et al., 1997; Rebhun, 2000). Esses fatores podem levar os animais à diminuição da produção de leite e ao baixo desempenho reprodutivo, causando prejuízos à atividade leiteira. No entanto, não há trabalhos que quantifiquem as perdas associadas à ocorrência de distúrbios respiratórios em bovinos, havendo a necessidade de estudos que busquem elucidar tal fato.

\subsection{Mastite}

A mastite caracteriza-se pelo processo inflamatório da glândula mamária, frente às agressões físicas, químicas, mecânicas ou microbianas. No entanto, 90\% das inflamações são causadas por bactérias (Wilson et al., 1997; Bueno et al., 2002). Além desses patógenos, fungos, leveduras, algas e vírus também podem estar envolvidos na etiologia da doença, porém a incidência é baixa (Pereira, 2000; Bueno et al., 2003).

A mastite pode ser dividida em dois grupos, conforme sua forma de manifestação. A forma clínica cursa com sinais evidentes, tais como: edema, hipertermia, endurecimento, dor na glândula mamária e/ou aparecimento de grumos, pus ou outras alterações das características do leite (Park \& Jacobson, 1996; Pereira, 2000). A forma subclínica se caracteriza por alterações na composição do leite; entre as principais alterações, destaca-se: aumento da contagem de células somáticas (CCS), aumento dos teores de $\mathrm{CL}^{-}$e $\mathrm{Na}^{+}$e diminuição da concentração de caseína, gordura, sólidos totais e lactose do leite. Segundo Philpot (1998), para cada caso de mastite clínica devem existir entre 15 a 40 casos sub-clínicos.

Diversos patógenos podem estar envolvidos na etiologia da mastite, caracterizando-a em duas classes: os causadores de mastite contagiosa ou primária e os 
de mastite ambiental ou secundária (Cullor et al., 1993; Fox, 1993; Bueno et al., 2002). Considera-se mastite contagiosa aquela causada por microrganismos bem adaptados à sobrevivência no úbere, que são transferidos de uma glândula infectada para outra sadia, especialmente durante a ordenha. Nessa categoria estão incluídos: o Streptococcus agalactiae e o Staphylococcus aureus (Cullor et al., 1993).

Alem desses patógenos mencionados, de "maior patogenicidade” ou "patógenos primários”, existem também os de "menor patogenicidade” ou "patógenos secundários”. Incluem o Corynebacterium bovis e o Staphylococccus coagulase negativa, bactérias que ao colonizarem a glândula mamária promovem reações inflamatórias medianas, no entanto, com apresentação de vários casos clínicos (Cullor et al, 1993).

A mastite ambiental ocorre quando bactérias que compartilham o mesmo ecossistema da vaca (solo, piso, cama, esterco e materiais orgânicos) têm acesso à glândula mamária (Cullor et al., 1993). A transferência dos microrganismos para o interior da glândula ocorre no intervalo entre ordenhas, mas a transmissão no decorrer da ordenha deve ser considerada (Philpot, 2002).

Uma grande variedade de organismos tem sido isolada a partir da glândula mamária. Watts (1988) referiu-se a 137 microrganismos entre espécies, subespécies e sorovariedades. O grau de exposição dos animais aos patógenos é seguramente uma das principais causas de variabilidade e prevalência da mastite entre rebanhos. No entanto, o "status" imunitário dos animais, os aspectos inerentes à interação do agente, hospedeiro e ambiente devem ser considerados (Edmonson, 2002).

\subsubsection{Células somáticas}

As células somáticas são normalmente células de defesa, principalmente leucócitos, que migram do sangue para o interior da glândula mamária, com o objetivo de combater agentes estranhos. Contudo, uma pequena parte é composta por células epiteliais, provenientes do processo natural de descamação do tecido secretor (Nickerson, 1985; Machado et al., 1999; Machado et al., 2000). 
Conseqüentemente, a contagem de células somáticas (CCS) do leite de uma vaca indica, de maneira quantitativa, o grau de infecção da glândula mamária (Machado et al., 1999; Pereira, 2000). Por sua vez, a CSS do leite do tanque indica o grau de infecção média de mastite do rebanho (Machado et al., 2000).

A glândula mamária sadia apresenta CCS entre 50 mil e 200 mil células/mL de leite (Harmon, 1994; Laevens et al., 1997; Wilson et al., 1997). O fator mais importante que afeta a CCS é o "status” de infecção da glândula mamária, embora existam outros fatores, tais como, variação diurna, estágio da lactação e estresse (Reneau, 1986; Harmon, 1994). A intensidade do aumento da CCS pode variar em função do tipo de patógeno, o que possibilita alguma inferência quanto ao tipo de microrganismo envolvido na etiologia da doença, em função da CCS.

Existem diversos procedimentos para determinar a CCS em amostras de leite. A CCS eletrônica, realizada por meio da citometria fluxométrica, constitui um dos principais métodos utilizados para sua determinação (Pereira, 2000). Esse método possui como vantagem em relação a outros disponíveis no mercado, a automatização, rapidez e precisão dos resultados. Há também a possibilidade de conservação das amostras à temperatura ambiente, que facilita o envio para os laboratórios e o fato de que os resultados não sofrem influência de interpretação do responsável pelo teste, como no “California Mastitis Test” (CMT) (Fonseca \& Santos, 2000).

\subsubsection{Mastite e produção de leite}

As perdas econômicas relacionadas à mastite se devem à diminuição da produção de leite, gastos com medicamentos, leite descartado, assistência veterinária, descarte prematuro de animais e diminuição da reprodução de vacas (Kirk \& Bartlett, 1988; Wilson \& Sears, 1992; Fonseca \& Santos, 2000; Bueno et al., 2002) Para os laticínios, ressalta-se a queda na qualidade do produto, em função da diminuição dos teores de caseína, gordura, lactose e aumento da atividade lipolítica e proteolítica do leite (Santos, 2002). 
Considerando apenas as perdas em decorrência da diminuição da produção de leite, Rajala-Schultz \& Gronh (1999), estudando o impacto da mastite clínica em 24.276 lactações, observaram redução da produção de leite, variando entre 110 e 550 kg (1,8 a 7,4\%), por lactação. Esses dados são semelhantes aos observados por Blowey (1986), que descreve decréscimo da produção de leite de 10\% na lactação, em conseqüência da enfermidade.

Quanto à mastite subclínica, diagnosticada por diferentes métodos, Langengger et al. (1981), ao compararem a produção de leite de tetos infectados e seus homólogos sadios, verificaram que a produção dos tetos mastíticos era 25,5\% menor que a dos normais. Verificaram ainda que essa diminuição era de 27,4\% para Staphylococcus sp.

Graaf \& Dwinger (1996), ao estudarem a mastite subclínica diagnosticada pelo CMT, em 2.186 vacas de rebanhos da Costa Rica, relataram perdas de 17,6\% na lactação. Considerando o diagnóstico realizado pela CCS, Haile-Mariam et al. (2001) destacam que o aumento da CCS está intimamente associado à diminuição da produção de leite, sendo que os prejuízos já são significativos com CCS variando entre 100 e 200 mil células/mL (Raubertas \& Shook, 1982). Recentemente, Coldebella (2003) mostrou que a diminuição da produção de leite já é evidente a partir de 17 mil cél/mL.

Para facilitar a quantificação e a interpretação das perdas em decorrência do aumento da CCS, o Programa Nacional de Melhoramento do Rebanho Leiteiro (DHIA) dos EUA adotou, em 1984, o método do escore linear (EL), determinado pela seguinte função (Shook, 1982):

$$
E L=\log _{2}\left(\frac{C C S}{100}\right)+3
$$

Considerando essa padronização, Reneau (1986) mostrou que para cada aumento de uma unidade de EL, ocorre diminuição de $181 \mathrm{~kg}$ de leite na lactação. Resultados similares foram encontrados por Feltrow et al. (1988) que relatam perdas de $190 \mathrm{~kg}$ a cada aumento do EL. 


\subsubsection{Mastite e reprodução}

Desde o início da década de 90, vários trabalhos têm relatado a associação entre mastite e reprodução, apontando alterações do intervalo entre cios e diminuição da duração da fase luteínica, principalmente em animais com mastite causada por microrganismos gram-negativos (Cullor, 1990; Moore et al., 1991; Barker et al., 1998). Acredita-se que as endotoxinas produzidas pelos microrganismos induzem a luteólise e dificultam a concepção, além de causar morte embrionária precoce (Cullor, 1990; Moore et al., 1991; Schrick et al., 2001). Outra hipótese levantada é que as bactérias gramnegativas estimulam a produção de prostaglandina $\mathrm{PGF}_{2 \alpha}$, resultando em regressão do corpo lúteo (Moore et al., 1991; Barker et al. 1998; Schrick et al., 2001).

Considerando o desempenho reprodutivo, foi demonstrado que quando uma vaca apresenta um caso clínico de mastite antes do primeiro serviço, ocorre aumento do número de dias para a ocorrência do primeiro serviço e, conseqüentemente, dos dias vazios, em comparação aos animais sadios (Cullor, 1990; Moore et al., 1991).

Santos et al. (2002) e Santos et al. (2003) estudaram a influência da

doença sobre as características reprodutivas de vacas holandesas. A ocorrência de mastite subclínica antes do $1^{\circ}$ serviço atrasa a manifestação do cio e, em conseqüência, aumenta o número de dias necessários para que ocorra a concepção. Por sua vez, Schrick et al. (2001), avaliando dados provenientes de 752 vacas, relataram que vacas que tiveram mastite, independente da forma, apresentaram aumento do número de serviços por concepção. 


\section{MATERIAL E MÉTODOS}

\subsection{Animais e instalações}

No estudo foram utilizados dados zootécnicos e sanitários de 2.084 lactações (sendo 1.042 referentes à lactação atual e 1.042 da lactação posterior), provenientes de 665 vacas da raça Holandesa, pertencentes ao rebanho comercial da Fazenda Colorado, localizada no município de Araras, estado de São Paulo.

As observações coletadas foram referentes aos animais que pariram no período de janeiro de 1998 a dezembro de 2002. As informações dos animais descartados não foram utilizadas no estudo.

Os animais foram criados em sistema "free-stalls", que possuíam ventiladores e aspersores, acionados automaticamente quando a temperatura ultrapassava os $23^{\circ} \mathrm{C}$. Os animais foram confinados em oito lotes considerando a ordem da lactação, sendo que as primíparas foram mantidas no mesmo lote até o final da lactação.

Em cada estábulo estavam disponíveis três cochos para água e um cocho ao longo do rancho para a alimentação dos animais, além do solário; cinco ranchos para as novilhas inseminadas, permanecendo nesse local até 260 dias de gestação. Um rancho para as vacas secas, sendo esse ambiente dividido em 3 por meio de correntes e um rancho para vacas no pré-parto, onde foram separadas novilhas das vacas de segunda cria ou mais.

A alimentação foi fornecida 8 vezes ao dia, sendo a primeira refeição às 5:00h e a ultima, às 21:00h. A dieta adotada foi total e única, composta de silagem de milho, silagem pré-secada de gramínea, farelo de soja, gérmen de milho, silagem de grão 
úmido de milho, farelo de glúten de milho, polpa cítrica e mistura mineral, em que o volumoso correspondeu a 48\% da dieta em matéria seca (MS).

A composição estimada média da dieta foi de 50,2\% de matéria seca (\% MS), 16,9\% de proteína bruta (\% MS), 4,5\% de extrato etéreo (\% MS), 18,6 \% de fibra em detergente ácido (\% MS), 31,4\% de fibra em detergente neutro (\%MS), 40,25 de carboidratos não-estrurais (\% MS), 6,6 de matéria mineral (\% MS) e 1,75 Mcal/kg de energia líquida para lactação, sendo o consumo projetado de matéria seca de 23,0 kg/dia.

\subsection{Coleta de dados}

Foram coletados dados de duas lactações seguidas (mesmo animal). Utilizou-se dados dos animais de $1^{\mathrm{a}}, 2^{\mathrm{a}}, 3^{\mathrm{a}}$ ou mais crias.

As informações coletadas foram referentes a variáveis explicativas: escore de condição corporal na secagem e ao parto, época do parto (verão=novembro a abril, inverno=maio a outubro), duração do período seco e ocorrência de doenças. As variáveis respostas foram: produção de leite no pico, produção de leite aos 305 dias e concepção ao primeiro serviço.

\subsubsection{Produção de leite e contagem de células somáticas}

Foram realizadas três ordenhas diárias. As produções de cada animal foram medidas e registradas eletronicamente. A produção de leite no pico (kg) e aos 305

dias (estimadas para as lactações não-encerradas) foi analisada utilizando o "Software Gerencial” do Programa de Análise de Rebanhos Leiteiros da Clínica do Leite, da Escola Superior de Agricultura “Luiz de Queiroz”/USP (Everet \& Carter, 1968).

A contagem de células somáticas (CCS) foi realizada mensalmente, coletando-se amostras de todos os animais, sempre na ordenha da manhã. O leite foi transferido diretamente do medidor para os frascos de coleta, com capacidade para 60 $\mathrm{mL}$ de leite, contendo 2 pastilhas de “bronopol” como conservante (IDF, 1996). Após homogeneização, as amostras foram enviadas ao laboratório de Fisiologia da Lactação, 
da Clínica do Leite, Departamento de Zootecnia da Escola Superior de Agricultura "Luiz de Queiroz”/USP.

A determinação da CCS foi realizada no máximo até 3 dias após coleta das amostras (IDF, 1984; Meyer et al., 2003). A CCS foi determinada por citometria de fluxo, pelo equipamento Somacount $300^{\circledR}$ (Bentley Instruments', 1995).

\subsubsection{Ocorrência de enfermidades}

As doenças foram diagnosticadas pelo mesmo veterinário e suas ocorrências registradas diariamente no "Software Agenda” da Clínica do Leite (ESALQ/ USP). Os registros foram realizados considerando ocorrência=1 ou não-ocorrência=0. Assim, apenas a primeira ocorrência foi considerada.

As doenças avaliadas no estudo foram: pneumonia até os 60 dias do pósparto e na lactação, afecções de casco até os 60 dias do pós-parto e na lactação, mastite clínica até os 60 dias do pós-parto e na lactação, mastite subclínica durante a lactação, mastite subclínica ao parto e doenças do periparto (febre do leite, deslocamento de abomaso, metrite, retenção de placenta e cetose). Quanto as afecções de casco, foram consideradas as seguintes enfermidades: dermatite digital, pododermatite necrosante, pododermatite asséptica difusa ou laminite, pododermatite circunscrita ou úlcera de sola, erosões e abscessos de sola (Greenough, 1986; Nocek, 1993). As descrições dos diagnósticos são apresentadas na Tabela 2. 
Tabela 2. Definições dos diagnósticos das enfermidades avaliadas no estudo

\begin{tabular}{|c|c|}
\hline Enfermidades & Definição \\
\hline Afecções de casco & Exame clínico geral e específico do casco. \\
\hline Cetose & $\begin{array}{l}\text { Determinação da presença de corpos cetônicos na urina através do } \\
\text { kit Ketostic-Bayer }^{\circledR}\end{array}$ \\
\hline Deslocamento de abomaso & Som metálico à auscultação e correção cirúrgica. \\
\hline Febre do Leite & $\begin{array}{l}\text { Fraqueza, hipotermia e resposta favorável à terapia endovenosa } \\
\text { com solução de cálcio. }\end{array}$ \\
\hline Mastite clínica & Alterações no leite, exame geral e alterações da glândula mamária. \\
\hline Mastite subclínica & $\begin{array}{l}\text { Número de vezes que o animal apresentou CCS superior a } 200 \text { mil } \\
\text { células/mL durante a lactação. }\end{array}$ \\
\hline Metrite & Corrimento vaginal e tamanho anormal do útero à palpação retal. \\
\hline Pneumonia & $\begin{array}{l}\text { Febre, tosse produtiva, estertores à auscultação pulmonar, } \\
\text { fraqueza e dificuldade respiratória. }\end{array}$ \\
\hline Retenção de placenta & Retenção das membranas fetais $>18$ horas após o parto \\
\hline
\end{tabular}

\subsubsection{Concepção ao primeiro serviço}

As vacas foram selecionadas para palpação a cada 14 dias aproveitando o momento para avaliação dos ciclos dos animais aptos para inseminação, sincronização, avaliação do útero no pós-parto, diagnóstico de gestação e necessidade de tratamento. A sincronização do cio das vacas ocorria geralmente 40 dias após o parto.

A atividade de cio foi monitorada pela observação dos animais com atividade excessiva, observada pelo podômetro e visualização comportamental. O período de espera voluntário adotado foi de 60 dias, portanto a inseminação foi realizada a partir do $1^{0}$ cio apresentado pelos animais após esse período. Após diagnóstico de prenhez por meio da palpação, as informações quanto à concepção ao primeiro serviço foram registradas como não-concepção ao primeiro serviço=0 e concepção ao primeiro serviço=1, na lactação atual e na lactação posterior. 


\subsubsection{Escore de condição corporal}

Foram avaliados o escore de condição corporal na secagem (ECCS) e ao parto (ECCP).

Foi utilizada a avaliação visual do escore de condição corporal (ECC), segundo metodologia descrita por Wildman et al. (1982), utilizando-se escala de 1(magra) a 5 (gorda), com intervalo de 0,25 ponto. As avaliações foram realizadas por único avaliador.

A aferição do ECC à secagem foi realizada no momento em que os animais foram transferidos para o lote pré-parto. Dessa maneira, tanto os animais primíparos como os multíparos (transferidos para o lote pré-parto 60 dias antes da data prevista para o parto) tiveram o escore de condição corporal avaliado (ECCS). No dia seguinte ao parto foram realizadas as aferições do ECC ao parto.

\subsection{Análise estatística}

Primeiramente, foi realizada a análise descritiva de todas as variáveis estudadas, apresentando-se a média, o desvio-padrão e os valores de mínimo e máximo.

A primeira contagem de células somáticas ( $\mathrm{x} \quad 10^{3}$ células $/ \mathrm{mL}$ ) foi transformada em logaritmo natural (LCCS), pois não possui distribuição normal (Godden et al., 2001).

Para a determinação dos fatores responsáveis por alterações na produção de leite no pico e aos 305 dias na lactação atual e na lactação posterior foi utilizada a análise de regressão múltipla, pelo método de seleção de variáveis "stepwise”, do procedimento REG do SAS ${ }^{\circledR}$ (1999).

Para a determinação dos fatores que afetaram a concepção ao primeiro serviço da lactação atual e da lactação posterior foram realizadas análises de regressão logística, calculando-se a "razão das chances" no procedimento LOGISTIC do SAS ${ }^{\circledR}$ (1999). A razão das chances trata-se de uma medida utilizada para aferir a associação entre variáveis independentes e dependentes. A razão das chances, constitui o "log" 
natural do parâmetro estimado obtido na análise de regressão logística. A razão das chances $=1,0$ indica que não existe nenhuma associação entre as variáveis respostas e explicativas, valores maiores ou menores que 1 indicam associação positiva ou negativa entre as variáveis, respectivamente (Domecq et al., 1997).

\subsection{Esquema geral do trabalho}

Na Figura 1 está apresentado o esquema geral do trabalho. Na $1^{\mathrm{a}}$ parte foi verificado o impacto das variáveis indicadas em vermelho sobre as indicadas em azul. $\mathrm{Na}$ $2^{\mathrm{a}}$ parte, o impacto das variáveis indicadas em vermelho sobre as indicadas em amarelo. Quanto a duração do período seco (verde), foi analisado o impacto dessa variável sobre as marcadas em amarelo.

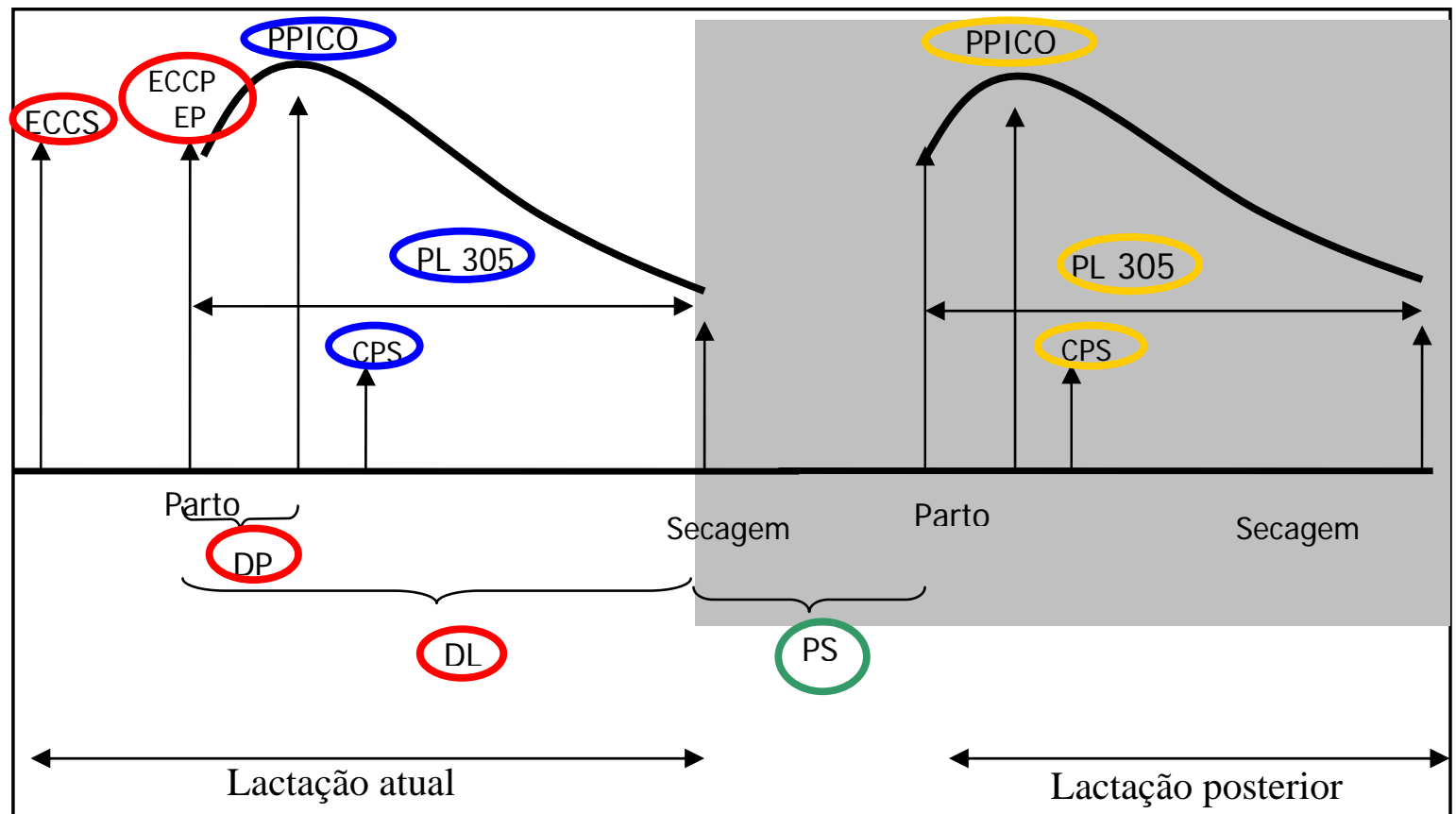

ECCS=Escore de condição corporal à secagem, ECCP= Escore de condição corporal ao parto, $\mathrm{EP}=$ Época do parto, $\mathrm{DP}=$ Doenças do periparto, $\mathrm{DL}=$ Doenças da lactação, $\mathrm{PPICO}=$ Produção de leite no pico, PL305=Produção de leite aos 305 dias, PS= Duração do período seco, CPS=Concepção ao primeiro serviço.

Figura 1- Esquema das variáveis explicativas e resposta, utilizadas no modelo final para avaliar o impacto dos eventos ocorridos antes e após o parto sobre a produção de leite no pico, produção de leite aos 305 dias e concepção ao primeiro serviço da lactação atual e da lactação posterior 


\section{RESULTADOS E DISCUSSÃO}

\subsection{Caracterização do rebanho}

\subsubsection{Análise das variáveis quantitativas}

Na Tabela 3 está apresentada a análise descritiva das variáveis quantitativas avaliadas.

Tabela 3. Análise descritiva das variáveis quantitativas

\begin{tabular}{lrrrr}
\hline Variável & Média & DP & Mínimo & Máximo \\
\hline Explicativas & & & & \\
ECC ${ }^{1}$ ao parto & 3,4 & 0,5 & 2,3 & 5,0 \\
ECC à secagem & 3,2 & 0,5 & 2,0 & 5,0 \\
$\quad$ Duração do período seco (dias) & 70,8 & 25,6 & 12,0 & 192,0 \\
CCS $^{2}$ (mil cél./mL) & 259,2 & 767,9 & 1,0 & 9999,0 \\
$\quad$ CCS alta durante a lactação $^{3}$ & 2,0 & 2,7 & 0,0 & 10,0 \\
Respostas & & & & \\
$\quad$ Produção de leite no pico (kg) & 40,5 & 8,5 & 15,4 & 72,4 \\
$\quad$ Produção de leite aos 305 dias (kg) & 9.819 & 1.800 & 3.514 & 15.582 \\
\hline
\end{tabular}

$\mathrm{DP}=$ Desvio-padrão

${ }^{1} \mathrm{ECC}=$ Escore de condição corporal

${ }^{2} \mathrm{CCS}=$ Contagem de células somáticas

${ }^{3}$ Número de vezes que a CCS foi superior 200 mil cél./mL, considerando 10 análises realizadas, sendo uma ao mês em um período de 10 meses.

Quanto às variáveis explicativas, observa-se que a média do ECC ao parto e à secagem (3,4 e 3,2, respectivamente) se apresentou conforme o preconizado. Wildman et al. (1982) recomendam para o período desde a secagem até o parto valores entre 3,0-4,0. No entanto, na propriedade estudada, também foram observados valores extremos. Fergusson et al. (1994) relatam que vacas muito magras, geralmente, apresentam menor 
produção, devido à pequena reserva de energia e proteína. Por sua vez, vacas muito gordas são mais susceptíveis a problemas metabólicos e infecções, refletindo na produção de leite.

A média de duração do período seco foi de 70 dias, ressaltando-se que a propriedade estudada utiliza período de 60 dias. No entanto, animais que apresentaram problema sanitário ou "status" nutricional, aferido pelo ECC, inferior ao recomendado, foram secos mais cedo. Por esse motivo, observa-se períodos de até 192 dias. Pesquisas nesse sentido recomendam período médio de 50 a 60 dias, para que ocorra o adequado descanso fisiológico do úbere (Sorensen \& Enevoldsen, 1991; Fonseca \& Santos, 2000). Entretanto, recentemente, trabalhos têm demonstrado que animais, com períodos de secagem inferiores aos citados (menor que 30 dias), podem apresentar bons resultados, não prejudicando a magnitude de produção de leite (Athie et al., 1996).

No que se refere à contagem de células somáticas, o rebanho estudado apresentou média inferior (259,2 mil cél./mL) à observada em rebanhos brasileiros (500 mil cél./mL) (Machado et al., 2000; Ribas et al., 2002). Em relação ao número de vezes que o animal apresentou contagem de células somáticas superior a 200 mil cél./mL, considerando 10 análises realizadas, ou seja, uma ao mês, a média do rebanho foi de 2 ocorrências durante a lactação (305 dias ou 10 meses).

Considerando a produção de leite, os índices apontam que o rebanho estudado apresenta alta produtividade $(9.819 \mathrm{~kg})$, sendo superior às médias observadas em rebanhos Holandeses dos estados de Minas Gerais, Paraná, Pernambuco e Goiás com produções de 6.300kg (Reis \& Silva, 1987), 6.400kg (Barbosa, 1990), 4.600kg (Richter et al., 1995) e 4.485kg (Ferreira \& Fernandes, 2000), respectivamente. 


\subsubsection{Freqüências qualitativas e quantitativas dos parâmetros avaliados}

Os resultados gerais das freqüências qualitativas e quantitativas avaliadas estão apresentados na Tabela 4.

Tabela 4. Análise descritiva das variáveis qualitativas e quantitativas discretas

\begin{tabular}{lrr}
\hline \multicolumn{1}{c}{ Variáveis } & Freqüência & \% das variáveis \\
\hline Explicativas: & & \\
Mastite clínica até 60 dias & 166 & 15,9 \\
Mastite clínica & 365 & 35,0 \\
Pneumonia até 60 dias & 49 & 4,7 \\
Pneumonia & 130 & 12,5 \\
Afecção de casco até 60 dias & 60 & 5,8 \\
Afecção de casco & 150 & 14,4 \\
Retenção de placenta & 150 & 14,4 \\
Cetose & 139 & 13,3 \\
Metrite & 99 & 9,5 \\
Deslocamento de abomaso & 32 & 3,1 \\
Febre do leite & 54 & 5,2 \\
Ordem de lactação & & \\
$1^{\text {a }}$ cria & 509 & 48,9 \\
$2^{\text {a }}$ cria & 334 & 32,0 \\
$3^{\text {a }}$ cria & 199 & 19,1 \\
Época do parto & & \\
Inverno & 647 & 62,1 \\
Verão & 395 & 37,9 \\
Resposta: & & 49,6 \\
CPS ${ }^{1}$ na lactação atual & 517 & 41,4 \\
CPS na lactação posterior & 431 &
\end{tabular}

${ }^{1} \mathrm{CPS}=$ Concepção ao primeiro serviço

Considerando as enfermidades avaliadas, a incidência de mastite clínica (35\%), retenção de placenta $(14,4 \%)$ e deslocamento de abomaso $(3,1 \%)$, foram similares aos resultados obtidos por Nicolau et al. (1992) que encontraram índice de 38,3\% para mastite, Risco (1992) que relatou 15,1\% de incidência de retenção de placenta e Markusfeld (1990) que descreveu índice de 2,5\% de casos de deslocamento de abomaso.

Para febre do leite (5,2\%), os resultados foram superiores aos encontrados por Markusfeld (1990) e Risco (1992) que destacaram índices variando entre 0,7 a 2,3\%, 
respectivamente. No entanto, Fourichon et al. (2001), ao estudarem rebanhos da França, observaram índices de 5,1\% de febre do leite.

Em relação às afecções de casco, metrite e cetose, os resultados foram inferiores ao observados por Markusfeld (1990), Risco (1992) e Molina et al. (1999) que observaram índices de 35\%, 30\% e 24,5\%, respectivamente, em rebanhos com manejos e produção similares ao deste estudo.

Quanto aos casos de mastite clínica, pneumonia e problemas de casco, observa-se que aproximadamente 45,5\%, 37,6\% e 40,3\% ocorreram durante os primeiros 60 dias de lactação, o que demonstra a necessidade de aumentar atenção nessa fase da vida produtiva dos animais. Esse período, denominado período de transição, refere-se ao tempo compreendido entre 3 semanas anteriores e 3 semanas posteriores à parição e é reconhecido como a fase mais crítica e desafiadora do ciclo de lactação, uma vez que a maioria das doenças metabólicas, infecciosas e reprodutivas se origina nessa fase, em razão, principalmente, de programas nutricionais inadequados (Drackley, 1999; Gonzáles \& Campos, 2003). A vaca leiteira sofre mudanças metabólicas durante as semanas finais da gestação, devido a mudanças no consumo alimentar e no estado hormonal que estão associadas à parição e ao início da lactação. A redução no consumo, observada algumas semanas antes da parição, pode atingir entre 10 e 30\%, se comparada com o consumo no início do período seco (Drackley, 1999), ao mesmo tempo em que a demanda por nutrientes para sustentar o crescimento do feto e o início da síntese do leite está aumentando. Portanto, qualquer erro nessa fase pode comprometer o "status” sanitário dos animais. 


\subsection{Impacto dos eventos ocorridos antes e após o parto sobre a produção de leite e reprodução de vacas Holandesas na lactação atual}

Nesta primeira parte da dissertação, foi verificado o impacto dos eventos ocorridos antes e após o parto sobre a produção de leite no pico, produção de leite aos 305 dias e concepção ao primeiro serviço da lactação atual.

Para a produção de leite no pico e concepção ao primeiro serviço foram consideradas as seguintes variáveis explicativas: época do parto, ECC na secagem e ao parto, duração do período seco, doenças do periparto (pneumonia até os 60 dias, afecção de casco até os 60 dias, mastite clínica até os 60 dias, logaritmo natural da primeira CCS (LCCS), febre do leite, deslocamento de abomaso, metrite, retenção de placenta e cetose). Para a produção de leite aos 305 dias, além das citadas anteriormente, foram estudadas: doenças da lactação (pneumonia na lactação, problema de casco na lactação, mastite clínica na lactação e mastite subclínica durante a lactação).

Em todas as análises realizadas foi verificada a possível interação entre a ordem da lactação e os fatores isolados, devido à heterogeneidade de variância observada entre os animais de $1^{\mathrm{a}}, 2^{\mathrm{a}}$ e $3^{\mathrm{a}}$ cria. 


\subsubsection{Impacto dos eventos ocorridos antes e após o parto sobre a produção de leite no pico}

Na Figura 2 estão apresentadas as variáveis pesquisadas. Ressalta-se que a variável resposta (PPICO) está marcada em azul, enquanto as variáveis explicativas estão em vermelho (ECCS, ECCP, EP e DP). Também foi verificado o impacto da duração do período seco (verde) sobre a produção de leite no pico (amarelo) da lactação posterior.

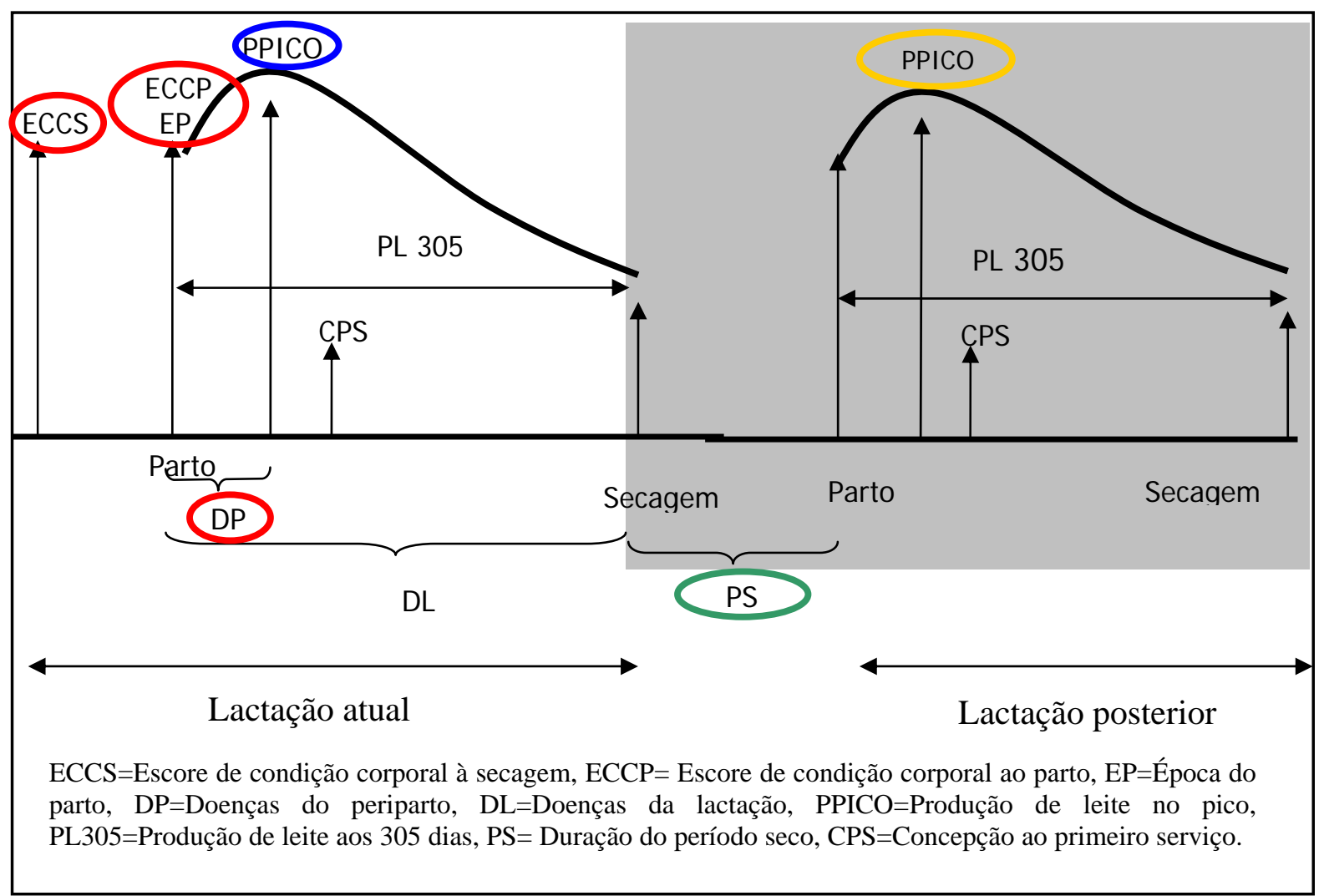

Figura 2- Esquema das variáveis explicativas e resposta, utilizadas no modelo final para avaliar o impacto dos eventos ocorridos antes e após o parto sobre a produção de leite no pico 
Na Tabela 5 estão apresentados os impactos dos eventos, ocorridos antes e após o parto, responsáveis por alterações na produção de leite no pico.

Tabela 5. Fatores responsáveis por alterações no pico de produção de leite em vacas Holandesas

\begin{tabular}{|c|c|c|c|}
\hline Variáveis Explicativas & Estimativas (kg) & Erro-padrão & $\operatorname{Pr}>|t|$ \\
\hline$\left(\mathrm{R}^{2}=\right.$ & $0,4270)$ & & \\
\hline Época do parto (verão vs. inverno) & & & \\
\hline Época do parto nos animais de $1^{\mathrm{a}}$ cria & $-8,4$ & 3,6 & 0,2040 \\
\hline Época do parto nos animais de $2^{\mathrm{a}}$ cria & $-18,0$ & 4,2 & $<0,0001$ \\
\hline Época do parto nos animais de $3^{\mathrm{a}}$ cria & $-9,6$ & 4,0 & 0,0174 \\
\hline $\mathrm{ECC}^{1}$ ao parto & 1,6 & 0,4 & 0,0002 \\
\hline ECC à secagem & & & \\
\hline ECC à secagem nos animais de $1^{\mathrm{a}}$ cria & $-3,4$ & 0,8 & $<0,0001$ \\
\hline ECC à secagem nos animais de $2^{\mathrm{a}}$ cria & $-0,6$ & 0,7 & 0,5297 \\
\hline ECC à secagem nos animais de $3^{\mathrm{a}}$ cria & $-3,6$ & 0,8 & $<0,0001$ \\
\hline Duração do período seco & & & \\
\hline Efeito linear & 0,14 & 0,04 & $<0,0001$ \\
\hline Efeito quadrático & $-0,0007$ & 0,0002 & 0,0001 \\
\hline $\mathrm{LCCS}^{2}$ & & & \\
\hline LCCS nos animais de $1^{\mathrm{a}}$ cria & $-0,2$ & 0,3 & 0,5297 \\
\hline LCCS nos animais de $2^{\mathrm{a}}$ cria & $-1,7$ & 0,3 & $<0,0001$ \\
\hline LCCS nos animais de $3^{\mathrm{a}}$ cria & $-1,3$ & 0,4 & 0,0004 \\
\hline Retenção de placenta & & & \\
\hline Retenção de placenta nos animais de $1^{\mathrm{a}}$ cria & 0,8 & 0,8 & 0,3130 \\
\hline Retenção de placenta nos animais de $2^{\mathrm{a}}$ cria & $-4,3$ & 1,0 & $<0,0001$ \\
\hline Retenção de placenta nos animais de $3^{\mathrm{a}}$ cria & $-2,9$ & 1,3 & 0,0222 \\
\hline Deslocamento de abomaso & $-2,9$ & 1,2 & 0,0159 \\
\hline Cetose & 2,5 & 0,6 & $<0,0001$ \\
\hline
\end{tabular}

${ }^{1}$ ECC=Escore de condição corporal.

${ }^{2}$ LCCS=Logaritmo natural (contagem de células somáticas)

${ }^{3}$ Número de vezes que a CCS foi superior 200 mil cél./mL, considerando 10 análises realizadas, uma ao mês, em um período de 10 meses.

Considerando o modelo final utilizado para determinar o impacto dos eventos ocorridos antes e após o parto sobre a produção de leite no pico, aproximadamente $43 \%\left(\mathrm{R}^{2}=0,4270\right)$ dos fatores responsáveis por alterações foram isoladas nesse estudo.

Quanto à época do parto, os animais que pariram no verão produziram menos leite no pico do que os paridos no inverno. Ressalta-se que os animais de $2^{\mathrm{a}}$ cria $(\mathrm{P}<0,0001)$ foram mais sensíveis ao estresse térmico do que os de $3^{\mathrm{a}}$ cria $(\mathrm{P}=0,0174)$. 
Porém, os de $1^{\mathrm{a}}$ cria não sofreram influência da época do parto $(\mathrm{P}=0,2040)$ sobre a produção de leite no pico. Segundo vários autores, a alta temperatura tem efeito inibidor sobre o consumo alimentar dos animais e destacam que apenas um episódio de temperatura alta (acima de $25^{\circ} \mathrm{C}$ ) pode determinar a redução do consumo em até 30\%, além de o animal aumentar o fluxo sanguíneo periférico na tentativa de reduzir a temperatura corpórea. Isso reduz a absorção de nutrientes e, em conseqüência, a disponibilidade desses para a glândula mamária, interferindo diretamente na produção de leite (Faust et al., 1988; Moore et al., 1991; Silva et al., 1992).

Quanto ao ECC ao parto, cada aumento de uma unidade do ECC ao parto representou 1,6 kg a mais de leite no pico, considerando o ECC corporal igual a 3,5. Observa-se que para tal variável não houve efeito da ordem da lactação, ou seja, os animais de $1^{\mathrm{a}}, 2^{\mathrm{a}}$ e $3^{\mathrm{a}}$ cria tiveram comportamentos semelhantes (Tabela 5). Fergusson et al. (1994) relatam que animais com escore de condição corporal acima de 4,0 são extremamente sensíveis a distúrbios metabólicos e doenças infecciosas, o que promove queda no consumo de alimentos e, em conseqüência, perda de condição corporal, que diminui a produção de leite. No entanto, Santos (1996), avaliando o efeito do ECC ao parto sobre o desempenho da lactação, não observou diferença na produção ou composição do leite entre dois grupos de vacas, gordas ou magras.

O ECC à secagem influenciou negativamente a produção de leite no pico. Cada aumento de uma unidade do ECC à secagem representou 3,41 kg e 3,66 kg a menos de leite no pico $(\mathrm{P}<0,0001)$, para os animais de $1^{\mathrm{a}}$ e $3^{\mathrm{a}}$ cria, respectivamente. No entanto, a produção de leite dos animais de $2^{a}$ cria não foi afetada (Tabela 5). Apesar da inexistência de trabalhos relacionando o ECC à secagem e produção de leite no pico, Domecq et al. (1997) sugerem que tal relação exista.

A duração do período seco apresentou efeito quadrático, ou seja, até o ponto máximo de 100 dias a vaca aumenta a produção de leite; a partir desse, as perdas são de aproximadamente 0,0007 kg de leite ao dia (Tabela 5). Athie et al. (1996) destacam que a duração do período seco constitui um importante ponto de manejo para as propriedades leiteiras, pois garante o descanso fisiológico ao úbere, sendo necessários de 50-60 dias entre o fim da lactação e o parto para que ocorra adequada regeneração das células 
secretoras de leite. No terço final da gestação o desenvolvimento do feto é acentuado e grande parte dos nutrientes ingeridos pela vaca vai para o processo de formação do bezerro. Se a vaca ainda estiver em lactação nessa fase, o desgaste orgânico será maior, o que prejudicará o feto, a condição corporal da vaca e, conseqüentemente, a produção de leite na lactação subseqüente (Sorensen \& Enevoldsen, 1991). Porém, recentemente, pesquisas têm demonstrado que pela manipulação da dieta, é possível a manutenção das características produtivas do animal, utilizando-se períodos inferiores a 30 dias ou até mesmo a inexistência de duração do período seco (Athie et al., 1996).

Para cada aumento unitário do LCCS, a produção de leite foi 1,71 kg e 1,30 kg a menos de leite no pico, para os animais de $2^{\mathrm{a}}(\mathrm{P}<0,0001)$ e $3^{\mathrm{a}}(\mathrm{P}=0,0004)$ cria, respectivamente (Tabela 5). Porém, o LCCS não influenciou a produção de leite dos animais de $1^{\mathrm{a}}$ cria $(\mathrm{P}=0$,5297). Vários autores têm relatado diminuição da produção de leite relacionada ao aumento da CCS (mastite subclínica) (Harmon, 1994; Laevens et al., 1997; Wilson et al. 1997; Machado et al., 1999, Pereira, 2000; Coldebella, 2003). Isso provavelmente devido ao fato que as células somáticas, ao serem direcionadas para a glândula mamária, destroem as células secretoras do alvéolo, diminuindo a produção de leite. Deve-se ressaltar a ação direta dos agentes microbianos (mecânica e por meio de metabólitos) sobre a glândula mamária (Haile-Mariam et al., 2001). Quanto aos animais de $1^{a}$ cria, Pereira (2000) também não obteve efeito do LCSS sobre a produção de leite.

A ocorrência de retenção de placenta provocou decréscimo na produção de leite no pico em 4,3 kg ( $\mathrm{P}<0,0001)$ e $2,8 \mathrm{~kg}(\mathrm{P}=0,0222)$ para os animais de $2^{\mathrm{a}}$ e $3^{\mathrm{a}}$ cria respectivamente. Entretanto, para os animais de $1^{\text {a }}$ cria, não foi observada a influência da ocorrência da retenção de placenta sobre a produção de leite $(\mathrm{P}=0$,5297) (Tabela 5). Esses resultados são corrobados aos encontrados por Lucey et al. (1986), Rowlands \& Lucey (1986) e Rajala-Schultz \& Grohn (1998). No entanto, Martin et al. (1986) não observaram efeito da ocorrência de retenção de placenta sobre a produção de leite.

O deslocamento de abomaso diminuiu a produção de leite no pico em 2,90 kg $(\mathrm{P}=0,0159)$ independente da ordem de lactação (Tabela 5). Na literatura consultada, não há relatos sobre a associação da ocorrência de deslocamento de abomaso e produção de 
leite ao pico; no entanto, autores relatam a influência da enfermidade sobre a produção total (Curtis et al., 1984; Eicker et al., 1996).

De todas as análises realizadas para determinação dos fatores responsáveis por alterações no pico e na produção de leite aos 305 dias, a ocorrência de cetose $(\mathrm{P}<0,0001)$ foi considerada uma variável de efeito positivo para a produção de leite, independente da ordem de lactação (Tabela 5). Porém, deve-se ressaltar que a cetose não aumenta a produção e, sim, que os animais de alta produção são mais susceptíveis à enfermidade. Esses dados são corrobados por Fleisher et al. (2001), que apontam que animais de alta produção são mais susceptíveis às doenças do pós-parto, entre essas, a cetose. 


\subsubsection{Impacto dos eventos ocorridos antes e após o parto sobre a produção de leite aos 305 dias}

Na Figura 3 estão apresentadas as variáveis pesquisadas. Ressalta-se que a variável resposta (PL305) está marcada em azul, enquanto as variáveis explicativas estão em vermelho (ECCS, ECCP, EP, DP e DL). Também foi verificado o impacto da duração do período seco (verde) sobre a produção de leite aos 305 dias (amarelo) da lactação posterior.

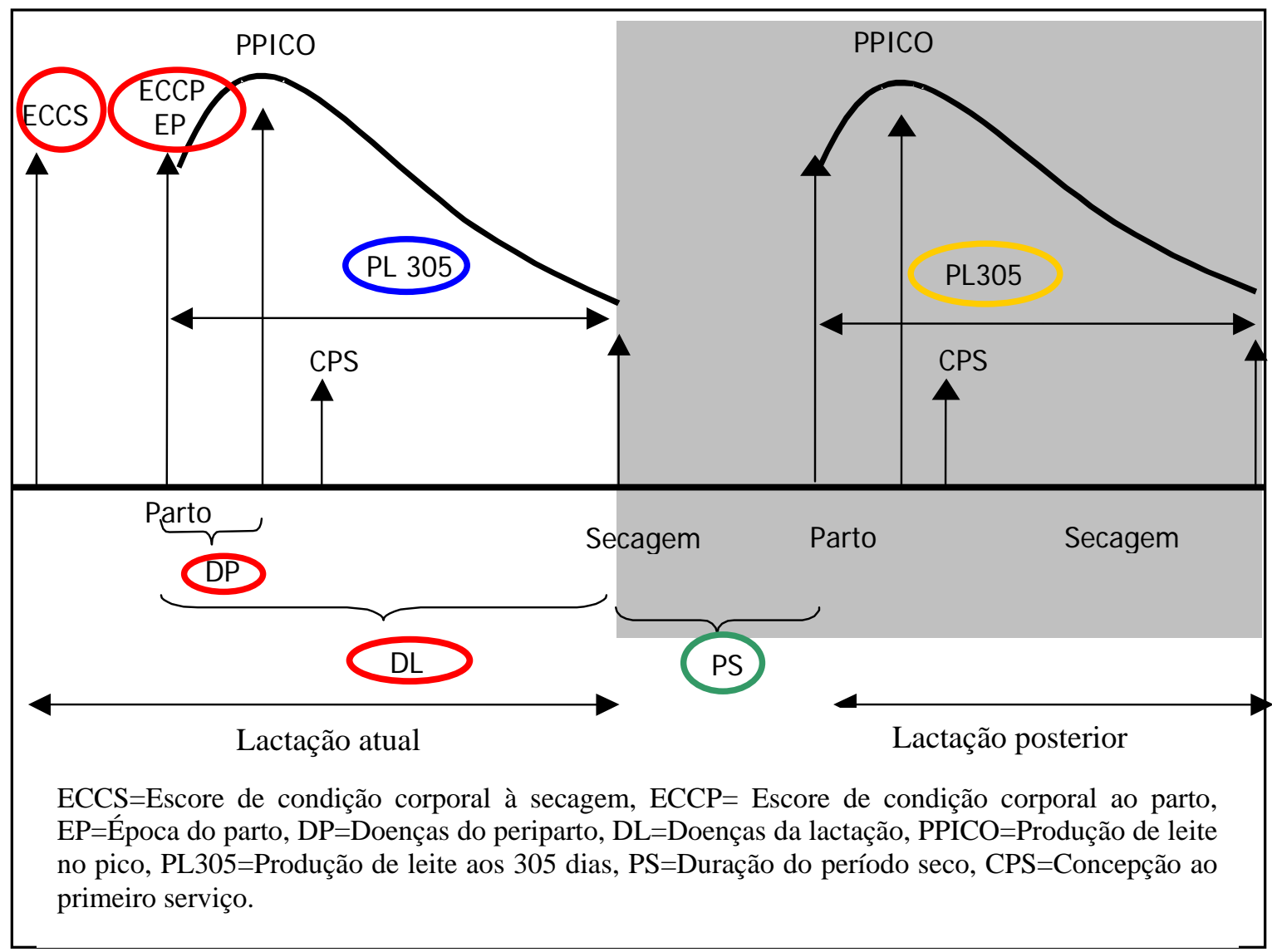

Figura 3- Esquema das variáveis explicativas e resposta, utilizadas no modelo final para avaliar o impacto dos eventos ocorridos antes e após o parto sobre a produção de leite aos 305 dias 
Na Tabela 6 estão apresentados os impactos dos fatores responsáveis por alterações na produção de leite aos 305 dias.

Tabela 6. Fatores responsáveis por alterações na produção de leite aos 305 dias, em vacas Holandesas

\begin{tabular}{|c|c|c|c|}
\hline Variáveis Explicativas & Estimativas & Erro-padrão & $\operatorname{Pr}>|t|$ \\
\hline \multicolumn{4}{|c|}{$\mathrm{R}^{2}=0,2444$} \\
\hline $\mathrm{ECC}^{1}$ ao parto & 462,8 & 101,4 & $<0,0001$ \\
\hline \multicolumn{4}{|l|}{ ECC à secagem } \\
\hline ECC à secagem nos animais $1^{\mathrm{a}}$ cria & $-733,1$ & 192,3 & $<0,0001$ \\
\hline ECC à secagem nos animais $2^{\mathrm{a}}$ cria & $-399,6$ & 164,4 & 0,0152 \\
\hline ECC à secagem nos animais $3^{\mathrm{a}}$ cria & $-1090,3$ & 197,4 & $<0,0001$ \\
\hline \multicolumn{4}{|l|}{ Duração do período seco } \\
\hline Efeito linear & 59,9 & 10,2 & $<0,0001$ \\
\hline Efeito quadrático & $-0,3$ & 0,05 & $<0,0001$ \\
\hline \multicolumn{4}{|l|}{$\operatorname{LCCS}^{2}$} \\
\hline LCCS nos animais $1^{\mathrm{a}}$ cria & $-17,5$ & 65,1 & 0,7876 \\
\hline LCCS nos animais $2^{\mathrm{a}}$ cria & $-416,6$ & 68,8 & $<0,0001$ \\
\hline LCCS nos animais $3^{\mathrm{a}}$ cria & $-227,8$ & 87,9 & 0,0097 \\
\hline \multicolumn{4}{|l|}{ Número de CCS ${ }^{3}$ alta na lactação } \\
\hline Número de CCS alta na lactação nos animais $1^{a}$ & 35,0 & 32,2 & 0,2776 \\
\hline Número de CCS alta na lactação nos animais $2^{a}$ & 145,8 & 36,5 & $<0,0001$ \\
\hline Número de CCS alta na lactação nos animais $3^{\mathrm{a}}$ & 140,1 & 42,8 & 0,0011 \\
\hline Mastite até os 60 dias & $-269,2$ & 137,1 & 0,0498 \\
\hline \multicolumn{4}{|l|}{ Retenção de placenta } \\
\hline Retenção de placenta nos animais $1^{\mathrm{a}}$ cria & 149,8 & 204,7 & 0,4645 \\
\hline Retenção de placenta nos animais $2^{\mathrm{a}}$ cria & $-992,1$ & 251,9 & $<0,0001$ \\
\hline Retenção de placenta nos animais $3^{\mathrm{a}}$ cria & $-501,1$ & 301,9 & 0,0972 \\
\hline Cetose & 557,9 & 149,9 & 0,0003 \\
\hline Deslocamento de abomaso & $-682,9$ & 289,0 & 0,0183 \\
\hline
\end{tabular}

${ }^{1}$ ECC=Escore de condição corporal

${ }^{2} \mathrm{CCS}=$ Logaritmo natural (contagem de células somáticas)

${ }^{3}$ Número de vezes que a CCS foi superior 200 mil cél./mL, considerando 10 análises realizadas, uma ao mês, em um período de 10 meses

Aproximadamente $25 \%\left(\mathrm{R}^{2}=0,2444\right)$ das alterações na produção de leite aos 305 dias neste estudo foram devidas aos fatores isolados no modelo final. Entre esses, se destaca o ECC à secagem. Para cada aumento de uma unidade do ECC à secagem, o animal produziu 733,1 kg ( $\mathrm{P}<0,0001)$, 399,6 kg ( $\mathrm{P}=0,0152)$ e 1090,3 kg $(\mathrm{P}<0,0001)$ a menos de leite na lactação, para os animais de $1^{\mathrm{a}}, 2^{\mathrm{a}}$ e $3^{\mathrm{a}}$ cria, respectivamente (Tabela 6). Esses resultados são similares ao encontrados por Garnsworthy (1988), Gearhart et al. 
(1990), Ruegg et al. (1992) e Fergusson (1994); contudo esses autores não consideraram a interação do ECC à secagem com a ordem de lactação.

Considerando a duração do período seco, tal variável apresentou efeito quadrático, ou seja, ocorre aumento da produção de leite no pico até 100 dias de duração do período seco e redução a partir desse ponto (Tabela 6). A duração do período seco é extremante importante para a maximização da produção de leite. Animais que são secos próximos ao parto não possuem tempo para que recomponham as células secretoras, influenciando a produção de leite na lactação subseqüente (Sorensen \& Enevoldsen, 1991; Fonseca \& Santos, 2000).

O LCCS influenciou a produção de leite, uma vez que para cada aumento unitário do LCCS, a produção de leite diminuiu 416,6 kg $(\mathrm{P}<0,0001)$ e 227,8 kg $(\mathrm{P}=0,0097)$ para os animais de $2^{\mathrm{a}}$ e $3^{\mathrm{a}}$ cria, respectivamente. Reneau (1986) e Feltrow et al. (1988) destacaram que para cada aumento de uma unidade do escore linear ocorreu diminuição de 181 kg e 190 kg de leite na lactação, respectivamente. Quanto aos animais de $1^{a}$ cria, o LCCS não apresentou efeito sobre a produção de leite (Tabela 6), resultados corrobados aos obtidos por Pereira (2000).

A ocorrência de mastite clínica até os 60 dias após o parto também constituiu um fator importante para a diminuição da produção de leite, independente da ordem de lactação ( $\mathrm{P}=0,0498)$. Os animais enfermos apresentaram redução na produção de leite de 269,2 kg (2,9\%) na lactação (Tabela 6). Vários pesquisadores afirmam que o estresse e a ação bacteriana (local ou sistêmica), apresentados pelos animais enfermos, diminuem a produção de leite (Hortet \& Seegers,1998; Fonseca \& Santos, 2000). Deluyker et al. (1993) e Rajala-Schultz \& Grohn (1999) observaram que as perdas em decorrência da mastite clínica foram de 5,0\% e entre 1,8 a 7,0\%, respectivamente, em rebanhos Holandeses, apresentando, portanto, perdas superiores às obtidas neste estudo.

A retenção de placenta provocou um decréscimo de 992,1 kg e 501,1 kg, para os animais de $2^{\mathrm{a}}(\mathrm{P}<0,0001)$ e $3^{\mathrm{a}}$ cria $(\mathrm{P}=0,0972)$, respectivamente. Esses resultados foram similares aos observados por Van Werven et al. (1992), que relatam perdas de 7\% na lactação em vacas que tiveram retenção de placenta. Porém, Martin et al. (1986) não observaram efeito da ocorrência da doença sobre a produção de leite aos 305 dias. Quanto 
aos animais de $1^{\mathrm{a}}$ cria, não foi verificada influência da doença sobre a produção de leite (Tabela 6). Resultados similares foram obtidos por Simerl et al. (1992) e Van Werven et al. (1992) que destacam diminuição da produção de leite apenas em animais multíparos.

Os animais que apresentaram deslocamento de abomaso no pós-parto produziram 682,9 kg ( $\mathrm{P}=0,0183)$ de leite a menos na lactação, independente da ordem de lactação (Tabela 6). Eikier (1995) relata que vacas tratadas que permaneceram no rebanho produziram 350 kg a menos no mês seguinte à ocorrência da doença, devido, principalmente, à inapetência e ao estresse apresentado pelos animais acometidos.

O ECC ao parto teve efeito positivo sobre a produção de leite aos 305 dias, sendo que para cada aumento de uma unidade de ECC ao parto, a produção de leite aumentou 462,7 kg (P<0,0001) na lactação. Esses resultados são semelhantes aos obtidos por Ruegg \& Milton (1995), que observaram que vacas com maior reserva corporal ao parto produzem mais leite. Porém, Gearhart et al. (1990) relatam que animais com elevada condição corporal ao parto (superior 4,0) são mais susceptíveis a perder condição corporal durante a lactação e, conseqüentemente, diminuir a produção de leite.

Observa-se também que animais com CCS alta durante a lactação tiveram maior produção de leite (Tabela 6). Ressalta-se que esse efeito foi observado apenas para os animais de $2^{\mathrm{a}}$ e $3^{\mathrm{a}}$ cria $(\mathrm{P}<0,0001)$. Tal fato contraria a literatura (Raubertas \& Shock, 1982). No entanto, Gandini et al. (1997) relatam que o aumento da CCS está relacionado geneticamente com a produção de leite. Pereira (2000) também observou que a CCS não influenciou a produção de leite em animais primíparos. Considerando a propriedade estudada, esses resultados podem ser em decorrência do baixo índice de CCS alta durante a lactação (considerando em 10 meses de análise, foi apenas de duas vezes). 


\subsubsection{Impacto dos eventos ocorridos antes e após o parto sobre a concepção ao primeiro serviço}

Na Figura 4 estão apresentadas as variáveis pesquisadas. Observa-se que a variável resposta (CPS) está marcada em azul enquanto as variáveis explicativas estão em vermelho (ECCS, ECCP, EP e DP). Também foi verificado o impacto da duração do período seco (verde) sobre a concepção ao primeiro serviço (amarelo) da lactação posterior.

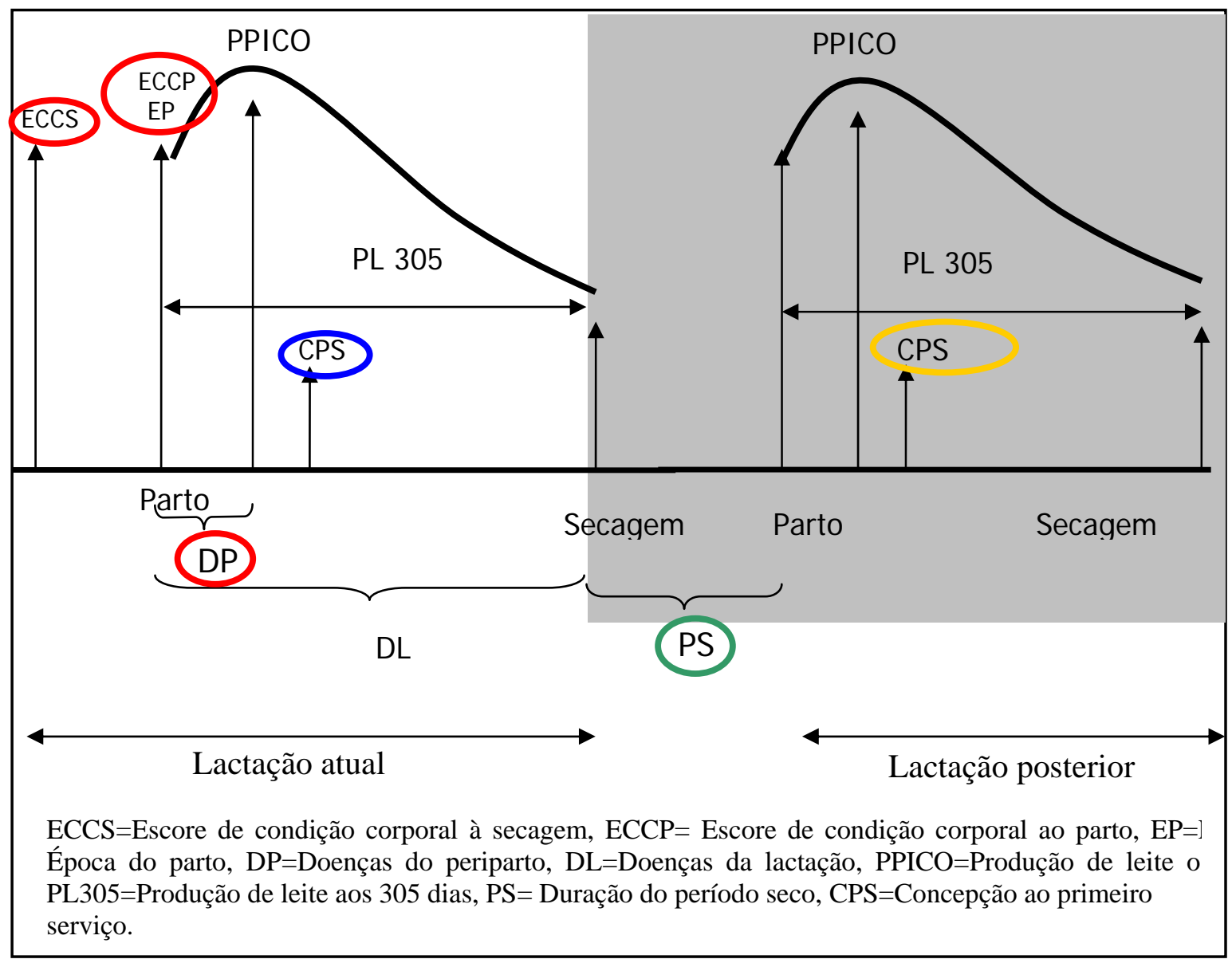

Figura 4- Esquema das variáveis explicativas e resposta, utilizadas no modelo final para avaliar o impacto dos eventos ocorridos antes e após o parto sobre a concepção ao primeiro serviço 
Na Tabela 7 estão apresentados os fatores responsáveis pelas alterações na concepção ao primeiro serviço de vacas Holandesas.

Tabela 7. Razão das chances e nível descritivo de probabilidade da regressão logística para os fatores associados à concepção ao primeiro serviço na lactação

\begin{tabular}{lcc}
\hline Variáveis Explicativas & Razão das chances & $\operatorname{Pr}>\chi^{2^{*}}$ \\
\hline Ordem da lactação & & \\
1 vs. 2 & 1,19 & 0,3576 \\
1 vs. 3 & 2,10 & 0,0006 \\
2 vs. 3 & 1,77 & 0,0129 \\
Época do parto (verão vs. inverno) & & \\
$\quad$ Época do parto nos animais $1^{\text {a }}$ cria & 1,09 & 0,6531 \\
$\quad$ Época do parto nos animais 2 ${ }^{\text {a }}$ cria & 0,45 & 0,0006 \\
$\quad$ Época do parto nos animais 3 ${ }^{\text {a }}$ cria & 0,66 & 0,2020 \\
ECC ${ }^{1}$ ao parto & 0,69 & $<0,0001$ \\
Duração do período seco & & \\
$\quad$ Duração do período seco nos animais $1^{\text {a }}$ cria & 0,97 & $<0,0001$ \\
$\quad$ Duração do período seco nos animais $2^{\text {a }}$ cria & 0,99 & 0,0060 \\
$\quad$ Duração do período seco nos animais 3 ${ }^{\text {a }}$ cria & 0,98 & 0,0219 \\
\hline
\end{tabular}

${ }^{*} \operatorname{Pr}>\chi^{2}=$ Nível descritivo de probabilidade $(\mathrm{P})$

${ }^{1}$ ECC $=$ Escore de condição corporal

Observa-se que as vacas de $1^{\mathrm{a}}$ lactação possuem índice de concepção ao primeiro serviço (CPS) superior aos de $3^{\mathrm{a}}$ lactação (Razão das chances=2,10, $\mathrm{P}=0,0006$ ) (Tabela 7). As de $2^{\mathrm{a}}$ lactação também possuem CPS superior às de $3^{\mathrm{a}}$ lactação (Razão das chances= 1,77, P=0,0129). Nebel \& McGilliard (1993) e Farin et al. (1994) relatam que animais de maior produção de leite são menos férteis do que as de menor produção. Contudo, deve-se considerar que esses animais possuem alta taxa metabólica, portanto são mais susceptíveis às condições de estresse que, por sua vez, influenciam a reprodução.

Quanto à época do parto, apenas para os animais de $2^{\mathrm{a}}$ cria (Tabela 7) 0 efeito foi significativo, sendo que os animais que pariram no verão tiveram menor chance $(0,45)$ de concepção que pariram no inverno $(\mathrm{P}=0,0006)$.

O ECC ao parto afetou a concepção ao primeiro serviço (Tabela 7). Animais que apresentaram aumento de uma unidade de ECC ao parto tiveram menor chance $(0,66)$ de concepção, não apresentando efeito da ordem de lactação $(\mathrm{P}<0,0001)$. Animais com alta condição corporal apresentam maior intervalo entre o parto e a primeira ovulação, maior 
período de serviço e menor taxa de concepção ao primeiro serviço. Animais gordos consomem menos matéria seca que os magros; esta menor ingestão pode predispor os animais a problemas metabólicos que interferem na capacidade reprodutiva (Edmonson et al., 1989; Gearhart et al.,1990 e Nebel \& McGilliard, 1993). Porém, Garnsworthy (1988) relata que o ECC ao parto não afetou a taxa de concepção, mas destaca que mudanças bruscas no ECC entre o parto e a concepção podem influenciar negativamente a taxa de concepção.

A duração do período seco não teve efeito significativo sobre a concepção $(0,98 \cong 1,0)$. O efeito observado foi praticamente o mesmo para os animais de $1^{\mathrm{a}}, 2^{\mathrm{a}}$ e $3^{\mathrm{a}}$ cria. Mas ressalta-se que a duração do período seco é indispensável para que o animal reponha suas reservas corporais, facilitando o aparecimento do cio pós-parto. A duração do período seco recomendado varia entre 60-90 dias, porém estudos recentes apontam que esse período pode ser diminuído (Athie et al., 1996).

\subsection{Impacto dos eventos ocorridos na lactação sobre a produção de leite e reprodução da lactação posterior}

Nessa segunda parte da dissertação foi verificado o impacto dos eventos ocorridos na lactação sobre a produção de leite no pico, produção de leite aos 305 dias e concepção ao primeiro serviço na lactação posterior.

Foram avaliadas as seguintes variáveis explicativas: época do parto, ECC na secagem e ao parto, pneumonia até os 60 dias pós-parto e na lactação, problema de casco até os 60 dias pós-parto e na lactação, mastite clínica até os 60 dias pós-parto e na lactação, logaritmo natural da primeira CCS (LCCS), febre do leite, deslocamento de abomaso, metrite, retenção de placenta e cetose. Considerou-se a interação entre os fatores pesquisados e a ordem de lactação. 


\subsubsection{Impacto dos eventos ocorridos na lactação sobre a produção de leite no pico da lactação posterior}

Na Figura 5 estão apresentadas as variáveis pesquisadas. Nota-se que a variável resposta (PPICO) está marcada em amarelo, enquanto as variáveis explicativas estão em vermelho (ECCS, ECCP, EP, DP e DL).

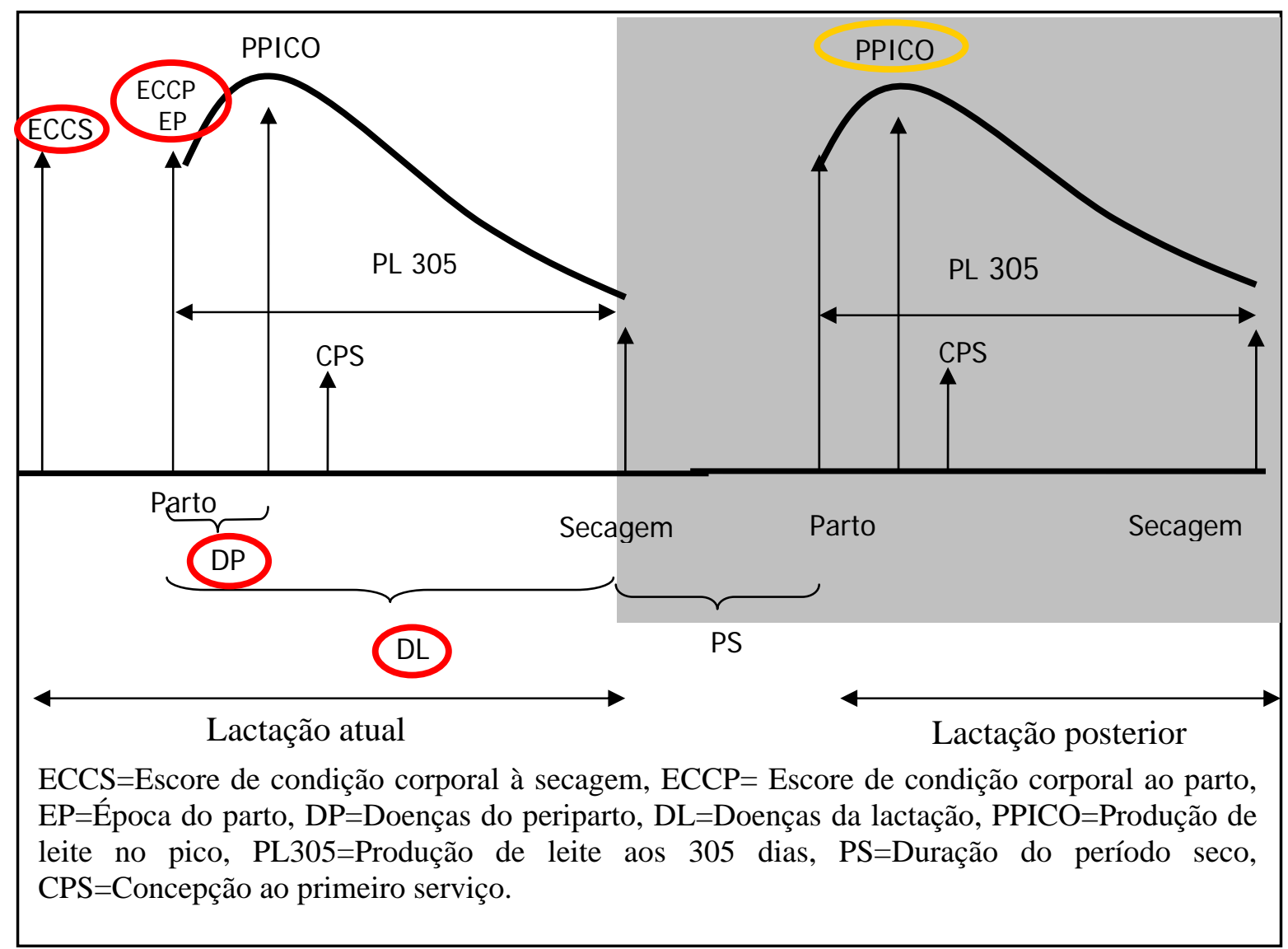

Figura 5- Esquema das variáveis explicativas e resposta, utilizadas no modelo final para avaliar o impacto dos eventos ocorridos na lactação sobre a produção de leite no pico da lactação posterior 
Na Tabela 8 estão apresentados os impactos dos eventos ocorridos na lactação sobre a produção de leite no pico da lactação posterior.

Tabela 8. Efeito dos fatores ocorridos na lactação anterior sobre a produção de leite no pico da lactação posterior de vacas Holandesas

\begin{tabular}{|c|c|c|c|}
\hline Variáveis Explicativas & Estimativas (kg) & Erro-padrão & $\operatorname{Pr}>|t|$ \\
\hline \multicolumn{4}{|c|}{$\mathrm{R}^{2}=0,0840$} \\
\hline Época do parto (verão vs. inverno) & $-1,0$ & 0,5 & 0,0529 \\
\hline \multicolumn{4}{|l|}{ ECC $^{1}$ à secagem } \\
\hline Efeito linear & 10,7 & 4,8 & 0,0261 \\
\hline Efeito quadrático & $-1,4$ & 0,7 & 0,0403 \\
\hline $\mathrm{LCCS}^{2}$ & $-0,5$ & 0,2 & 0,0109 \\
\hline Número de CCS alta na lactação ${ }^{3}$ & 0,3 & 0,1 & 0,0021 \\
\hline Mastite até 60 dias & $-1,4$ & 0,7 & 0,0385 \\
\hline \multicolumn{4}{|l|}{ Cetose } \\
\hline Cetose nos animais $1^{\mathrm{a}}$ cria & 3,2 & 0,9 & 0,0006 \\
\hline Cetose nos animais $2^{\mathrm{a}}$ cria & 1,4 & 1,7 & 0,4100 \\
\hline Cetose nos animais $3^{\mathrm{a}}$ cria & 1,0 & 1,7 & 0,5328 \\
\hline
\end{tabular}

${ }^{1}$ ECC=Escore de condição corporal

${ }^{2}$ LCCS $=$ Logaritmo natural (contagem de células somáticas)

${ }^{3}$ Número de vezes que a CCS foi superior 200 mil cél./mL, considerando 10 análises realizadas, uma ao mês, em um período de 10 meses

Pela análise do modelo final, observa-se que menos de $8,4 \%\left(\mathrm{R}^{2}=0,0840\right)$ do impacto sobre a produção de leite no pico da lactação posterior foram devidos a fatores ocorridos na lactação anterior, ou seja, mais de 92\% dos fatores responsáveis por alterações na produção de leite ao pico na lactação não foram isolados no modelo pesquisado.

Um fator que deve ser contemplado na interpretação dos resultados obtidos é a interação entre fatores. Por exemplo, neste estudo os animais que pariram no verão produziram $1,0 \mathrm{~kg}(\mathrm{P}=0,0529)$ a menos de leite no pico comparados aos que pariram no inverno (Tabela 8). No entanto, o impacto desse fator não deve ser analisado isolado, ou seja, esses animais que pariram no verão pode ter tido uma doença, ou escore de condição corporal inadequado, portanto a associação desses fatores pode ter contribuído para a diminuição na produção de leite no pico. Assim, esse mesmo raciocínio deve ser considerado para todas as variáveis isoladas, que estão descritas a seguir. 
O ECC à secagem apresentou efeito quadrático. Há um ponto ótimo para o ECC à secagem $(3,8)$ no que se refere à maximização da produção de leite no pico. Portanto, para cada aumento de uma unidade do ECC à secagem na lactação anterior, a produção de leite diminui em $1,4 \mathrm{~kg}(\mathrm{P}=0,0403)$ de leite no pico na lactação posterior (Tabela 8).

Considerando o LCCS, para cada aumento unitário do LCCS na lactação anterior, o animal produziu $0,53 \mathrm{~kg}(\mathrm{P}=0,0109)$ a menos de leite no pico da lactação posterior, independente da ordem de lactação (Tabela 8).

A ocorrência de mastite clínica durante a lactação anterior afetou negativamente $(\mathrm{P}=0,0021)$ a produção de leite ao pico da lactação posterior. Animais que apresentaram a doença produziram $1,4 \mathrm{~kg}$ a menos de leite no pico (Tabela 8). Tal variável não foi influenciada pela ordem da lactação.

A ocorrência de cetose na lactação anterior não teve efeito sobre a produção de leite ao pico da lactação posterior, para os animais de $2^{\mathrm{a}}$ e $3^{\mathrm{a}}$ cria, respectivamente (Tabela 8). Contudo, para os animais de $1^{\mathrm{a}}$ cria o efeito foi positivo sobre a produção de leite $(\mathrm{P}=0,0006)$.

Entretanto, não foram encontrados estudos relacionando fatores ocorridos na lactação anterior sobre a produção de leite no pico da lactação posterior, dificultando assim a discussão dos resultados. 


\subsubsection{Impacto dos eventos ocorridos na lactação sobre a produção de leite aos 305} dias da lactação posterior

Na Figura 6 estão apresentadas as variáveis pesquisadas. Observa-se que a variável resposta (PL305) está marcada em amarelo, enquanto as variáveis explicativas estão em vermelho (ECCS, ECCP, EP, DP e DL).

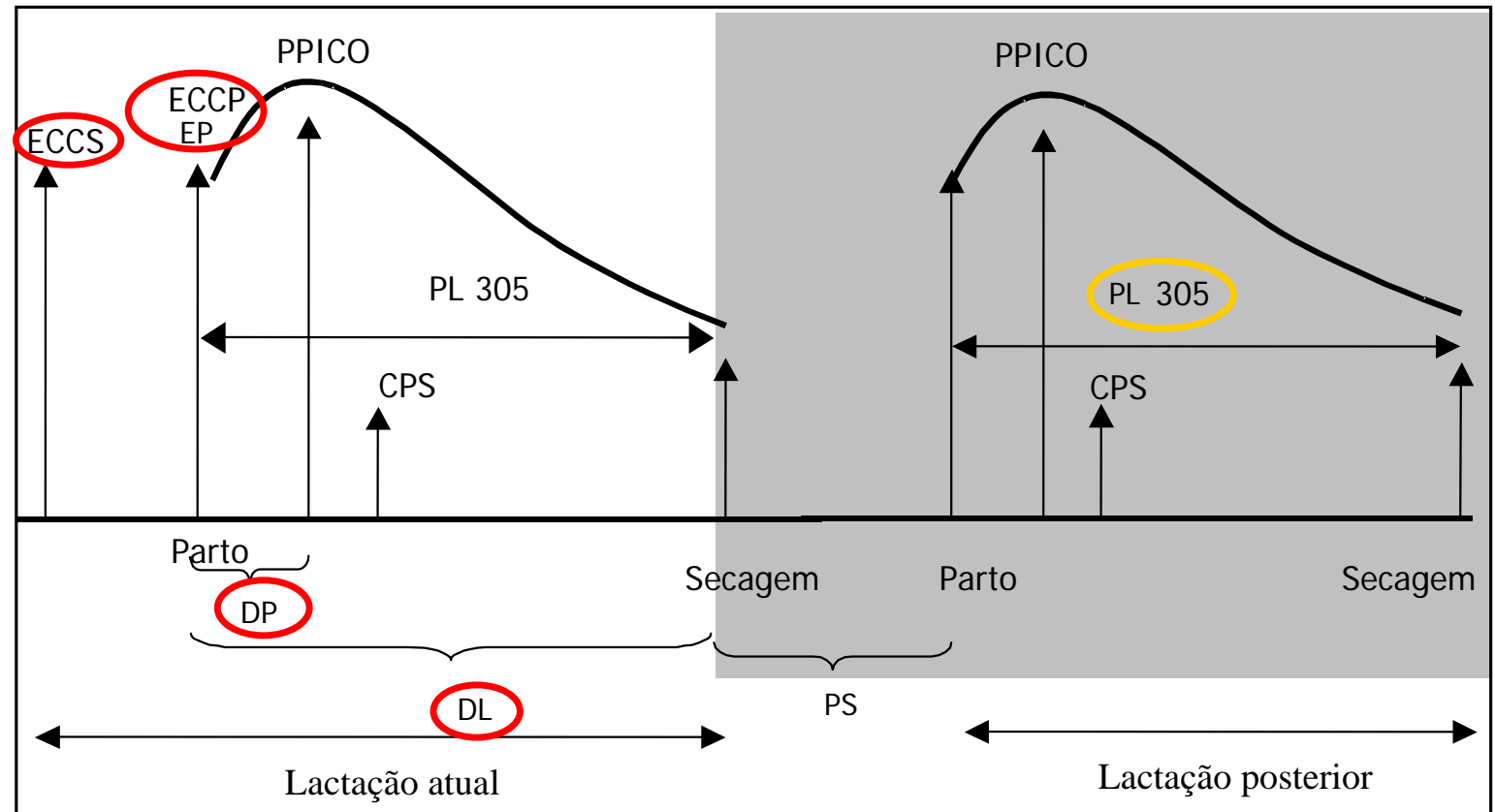

ECCS=Escore de condição corporal à secagem, ECCP= Escore de condição corporal ao parto, EP=Época do parto, $\mathrm{DP}=$ Doenças do periparto, $\mathrm{DL}=$ Doenças da lactação, PPICO=Produção de leite no pico, PL305=Produção de leite aos 305 dias, PS=Duração do período seco, CPS=Concepção ao primeiro serviço.

Figura 6- Esquema das variáveis explicativas e resposta, utilizadas no modelo final para avaliar o impacto dos eventos ocorridos na lactação sobre a produção de leite aos 305 dias da lactação posterior 
Na Tabela 9 estão apresentados os impactos dos eventos ocorridos na lactação sobre a produção de leite estimada para os 305 dias da lactação posterior.

Tabela 9. Efeito dos fatores ocorridos na lactação sobre a produção de leite estimada para 305 dias na lactação posterior de vacas Holandesas

\begin{tabular}{|c|c|c|c|}
\hline Variáveis Explicativas & Estimativas (Kg) & Erro-padrão & $\operatorname{Pr}>|t|$ \\
\hline \multicolumn{4}{|c|}{$\mathrm{R}^{2}=0,0600$} \\
\hline ECC $^{1}$ à secagem & 344,6 & 130,7 & 0,0085 \\
\hline Mastite até 60 dias & $-409,8$ & 165,0 & 0,0131 \\
\hline \multicolumn{4}{|l|}{ Cetose } \\
\hline Cetose nos animais $1^{\mathrm{a}}$ cria & 699,0 & 224,5 & 0,0019 \\
\hline Cetose nos animais $2^{\mathrm{a}}$ cria & $-31,7$ & 428,0 & 0,9409 \\
\hline Cetose nos animais $3^{\mathrm{a}}$ cria & $-155,0$ & 409,7 & 0,7052 \\
\hline
\end{tabular}

Menos que 6\% $\left(\mathrm{R}^{2}=0,0600\right)$ das alterações apresentadas na produção de leite aos 305 dias na lactação posterior foram devidos a alguns fatores ocorridos na lactação anterior. O aumento de uma unidade do ECC à secagem da lactação representou acréscimo de $344,6 \mathrm{~kg}$ de leite na lactação posterior $(\mathrm{P}=0,0085)$. Tal variável não foi influenciada pela ordem de lactação (Tabela 9). Ressalta-se que os efeitos dos fatores sobre a produção de leite não devem ser considerados isolados, conforme mencionado anteriormente.

Animais que apresentaram mastite clínica na lactação produziram 409,8 kg a menos de leite na lactação posterior $(\mathrm{P}=0,0131)$, independente da ordem de lactação (Tabela 9). Lucey \& Rowlands (1984), ao agruparem vacas multíparas de acordo com a produção, mostraram que vacas com média de $2.000 \mathrm{~kg}$ na lactação produziram $250 \mathrm{~kg}$ de leite a menos devido à mastite clínica na próxima lactação. Por outro lado, vacas com média de 4.450 e $7.000 \mathrm{~kg}$ produziram, respectivamente, 540 e $860 \mathrm{~kg}$ de leite a menos na lactação.

Quanto à ocorrência de cetose, não foi observada influência sobre a produção de leite para os animais de $2^{\mathrm{a}}$ e $3^{\mathrm{a}}$ cria. No entanto, para os animais de $1^{\mathrm{a}}$ cria foi observada interação entre ocorrência de cetose e produção de leite $(\mathrm{P}=0,0019)$. Observa-se que a ocorrência do distúrbio teve efeito positivo sobre a produção. 


\subsubsection{Impacto dos eventos ocorridos na lactação sobre a concepção ao primeiro serviço da lactação posterior}

Na Figura 7 estão apresentadas as variáveis pesquisadas. Ressalta-se que a variável resposta (CPS) está marcada em amarelo, enquanto as variáveis explicativas estão em vermelho (ECCS, ECCP, EP, DP e DL).

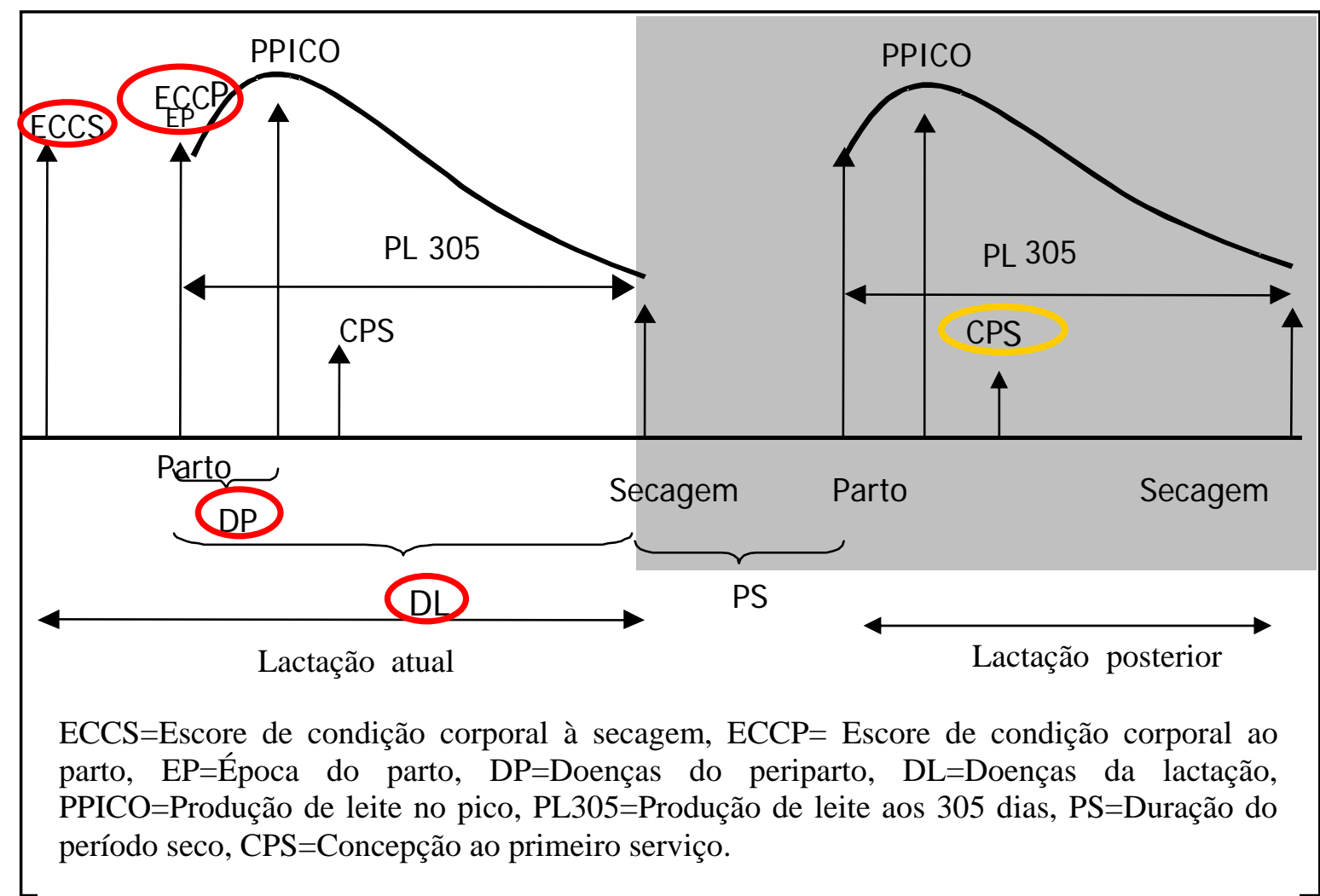

Figura 7- Esquema das variáveis explicativas e resposta, utilizadas no modelo final para avaliar o impacto dos eventos ocorridos na lactação sobre a concepção ao primeiro serviço da lactação posterior 
Na Tabela 10 estão apresentados os impactos dos fatores isolados na lactação sobre a concepção ao primeiro serviço da lactação posterior de vacas Holandesas.

Tabela 10. Razão das chances e nível descritivo de probabilidade da regressão logística para os fatores ocorridos na lactação anterior sobre a concepção ao primeiro serviço da lactação posterior

\begin{tabular}{|c|c|c|}
\hline Variáveis Explicativas & Razão das chances & $\operatorname{Pr}>\chi^{2 *}$ \\
\hline \multicolumn{3}{|l|}{ ECC $^{1}$ à secagem } \\
\hline ECC à secagem $1^{\mathrm{a}}$ cria & 0,40 & 0,0014 \\
\hline ECC à secagem $2^{\mathrm{a}}$ cria & 0,54 & 0,0210 \\
\hline ECC à secagem $3^{\mathrm{a}}$ cria & 0,80 & 0,4264 \\
\hline \multicolumn{3}{|l|}{ Número de CCS alta na lactação ${ }^{2}$} \\
\hline Número de CCS alta na lactação $1^{\mathrm{a}}$ cria & 0,93 & 0,0541 \\
\hline Número de CCS alta na lactação $2^{\mathrm{a}}$ cria & 0,87 & 0,0062 \\
\hline Número de CCS alta na lactação $3^{\mathrm{a}}$ cria & 0,95 & 0,3266 \\
\hline \multicolumn{3}{|l|}{ Pneumonia } \\
\hline Pneumonia $1^{\mathrm{a}}$ cria & 0,55 & 0,0452 \\
\hline Pneumonia $2^{\mathrm{a}}$ cria & 0,89 & 0,7651 \\
\hline Pneumonia $3^{\mathrm{a}}$ cria & 0,45 & 0,0839 \\
\hline \multicolumn{3}{|l|}{ Deslocamento de abomaso } \\
\hline Deslocamento de abomaso $1^{\mathrm{a}}$ cria & 0,23 & 0,0048 \\
\hline Deslocamento de abomaso $2^{\mathrm{a}}$ cria & 0,73 & 0,7993 \\
\hline Deslocamento de abomaso $3^{\mathrm{a}}$ cria & 1,31 & 0,7973 \\
\hline
\end{tabular}

${ }^{*} \mathrm{Pr}>\chi^{2}=$ Nível descritivo de probabilidade

${ }^{1}$ ECC $=$ Escore de condição corporal

${ }^{2}$ Número de vezes que a CCS foi superior 200 mil cél./mL, considerando 10 análises realizadas, uma ao mês, em um período de 10 meses

Considerando o impacto dos eventos ocorridos na lactação sobre a CPS da lactação posterior, destaca-se o ECC à secagem. Quanto maior o ECC à secagem na lactação anterior, menor a chance do animal conceber ao $1^{\circ}$ serviço na lactação posterior (Tabela 10). Observa-se que para os animais de $1^{\mathrm{a}}$ e $2^{\mathrm{a}}$ cria os efeitos foram significativos ( $\mathrm{P}=0,0014$ e $\mathrm{P}=0,0210$, respectivamente). Quanto aos de $3^{\mathrm{a}}$ cria, não houve efeito do ECC à secagem sobre a CPS. Vacas que apresentam ECC maior perdem mais condições corporais (gastam o excesso de reserva energética disponível na produção de leite) do que vacas com ECC baixo (Butler \& Smith, 1989). No entanto, Gearhart et al. (1990) ressaltam que vacas magras conseguem aumentar a ingestão de matéria seca mais rapidamente, 
alcançando o balanço energético positivo mais cedo do que vacas gordas. Dunn \& Kaltenbach (1980) relatam que a nutrição inadequada é conhecida como deletéria no retorno da atividade ovariana no pós-parto. O mecanismo mais provável de inibição da atividade reprodutiva seria a supressão da liberação dos picos de LH pela hipófise anterior, que é controlada pela liberação de GnRH no hipotálamo (Randel, 1990). A nutrição inadequada também pode afetar o tamanho do folículo dominante, que após a ovulação origina o embrião (Murphy et al., 1990). Portanto, valores extremos de ECC devem ser evitados.

Em relação à CCS, quanto maior o número de casos mastite sub-clínica na lactação anterior menor a chance de concepção ao primeiro serviço na lactação posterior, exceto para os animais de $3^{\mathrm{a}}$ cria $(\mathrm{P}=0,3266)$ (Tabela 10). Alguns autores têm relatado associação entre a ocorrência de mastite e diminuição das características reprodutivas. Os aspectos fisiológicos envolvidos em tal associação ainda não estão totalmente esclarecidos, mas acredita-se que as bactérias causadoras da mastite, principalmente gram-negativas, estimulam a produção de prostaglandina $\mathrm{PGF}_{2 \alpha}$ que resulta na regressão do corpo lúteo (Moore et al., 1991; Schrick et al., 2001). Outra questão é que a mastite pode alterar o padrão de secreção hormonal e o desenvolvimento folicular, uma vez que a inflamação da glândula mamária estimula a liberação de substâncias inibidoras de receptores dos hormônios reprodutivos, tais como folículo estimulante (FSH) e do hormônio luteinizante (LH). Além disso, o processo inflamatório promove elevação da temperatura corpórea, que aumenta as chances de morte embrionária (Moore et al., 1991).

Animais que apresentaram pneumonia na lactação anterior tiveram menor chance de concepção ao primeiro serviço na lactação posterior (Tabela 10), exceto para os animais de $2^{\mathrm{a}}$ cria $(\mathrm{P}=0,7651)$. A pneumonia tem sido associada à diminuição do consumo alimentar, fator que pode influenciar diretamente a habilidade reprodutiva. Outro fato é que animais enfermos são mais predispostos à infecção e ao estresse, fatores responsáveis por alterações na habilidade reprodutiva dos animais (Cardoso et al., 2002).

Os animais que apresentaram deslocamento de abomaso na lactação anterior tiveram menor chance de concepção ao primeiro serviço, observado apenas para os de $1^{\text {a }}$ cria $(\mathrm{P}=0,0048)$. Não se sabe perfeitamente qual a associação entre deslocamento de 
abomaso e reprodução. Acredita-se que o tratamento cirúrgico constitui em fator traumático, que pode diminuir o índice de produção e reprodução dos animais acometidos pelo distúrbio. Stengarde et al. (2002), ao estudarem o impacto do deslocamento de abomaso sobre as características reprodutivas em rebanhos da Suécia, relatam que as vacas acometidas pelo distúrbio, mesmo quando as medidas terapêuticas foram aplicadas adequadamente, apresentaram maior período de serviço e quase $11 \%$ dos animais não conceberam.

Contudo, apesar do efeito desses fatores sobre a concepção ao primeiro serviço, destaca-se que o $\mathrm{R}^{2}$ foi baixo $\left(\mathrm{R}^{2}=0,008\right)$. Portanto, pode-se considerar que os principais eventos responsáveis pelas alterações dos índices reprodutivos não foram isolados no modelo final. Além disso, não foi pesquisada a interação entre os fatores avaliados. 


\section{CONCLUSÕES}

Nas condições em que se realizou este estudo para vacas Holandesas, pode-se concluir que:

Para a lactação atual, os principais eventos que afetaram a produção de leite no pico foram: a época do parto, o escore de condição corporal à secagem e ao parto, a duração do período seco, o logaritmo natural da primeira contagem de células somáticas, a ocorrência de retenção de placenta, o deslocamento de abomaso e a cetose. Os mesmos eventos citados anteriormente, incluindo a ocorrência de mastite clínica e o número de casos de mastite sub-clínica durante a lactação afetaram a produção de leite aos 305 dias da lactação atual.

Considerando a concepção ao primeiro serviço da lactação atual, os resultados obtidos revelaram que a ordem de lactação, a época do parto (verão), o escore de condição corporal ao parto e a duração do período seco afetaram essa variável.

Quanto à lactação posterior, os eventos isolados na lactação anterior não influenciaram a produção de leite no pico, a produção de leite aos 305 dias e a concepção ao primeiro serviço. 


\section{REFERÊNCIAS BIBLIOGRÁFICAS}

ABILAY, T.A.; JOHSON, H.D.; MADAN, M. Influence of environmental heat on peripheral plasma progesterone and cortisol during the bovine estrous cycle. Journal of Dairy Science, v.58, p.1836-1840, 1975.

ANDERSSON, L.; GUSTAFSSON, A.H. Effect of hiperketonemia and feeding in fertility in dairy cows. Theriogenology, v.36, p.521-536, 1991.

ANDERSSON, R.R. Mammary gland. In: LARSON, B.L. (Ed). Lactation, Ames: The Iowa State University Press, 1985. cap.1, p. 3-38.

ANUALPEC, 2003. Anuário da Pesquisa Brasileira, São Paulo: FNP consultoria \& Agroinformativos, 2003. 400p.

ATHIE F.; BACHMAN, K.C.; HEAD, H.H. et al., Estrogen administered at final milk removal accelerates involution of bovine mammary gland. Journal of Dairy Science. v.79, p.220-226, 1996.

BANDINGA, L.; CVOLLIER, R.S.; WILCOX,C.J. et al., Interrelationship of milk, body wet, and reproductive performance. Journal of Dairy Science, v.68, p.18281831, 1984.

BARBOSA, C.D.O. Fatores não genéticos que influenciam o desempenho produtivo de rebanhos da raça holandesa no Estado de Minas Gerais. Lavras, 1995. 43p. Dissertação (Mestrado) - Faculdade de Zootecnia, Universidade Federal de Lavras.

BARBOSA, S.B.P. Estudo de características produtivas em rebanhos holandeses na bacia leiteira do Estado do Pernambuco. Viçosa, 1990. 121p. Tese (Doutorado)Universidade Federal de Viçosa. 
BARKER, A.R.; SCHICK, F.N.; LEWIS, M.J. et al., Influence of clinical mastitis during early lactation on reproductive performance of jersey cows. Journal of Dairy Science, v.81, p.1285-1290, 1998.

BENTLEY INSTRUMENTS. Somacount 300: operator's manual. Chaska, 1995. 12p.

BLOCK, E. Manipulating dietary anions and cations for prepartum dairy cows to reduce incidence of milk fever. Journal of Dairy Science, v.67, n.12, p.2939-2945, 1984.

BLOCK, E. The response the balance of major minerals by the dairy cow, In: GARNSWORTHY. P.G, Nutritional and lactation in the dairy cow, London: Butterworths-Heinemann, p. 119-134, 1988.

BLOOD, D. C; RADOSTITS, O.M. Clínica Veterinária: Rio de Janeiro: Guanabara, 1987. 860p.

BLOWEY, R.W. Assessment of the economic benefits of a mastitis control scheme. Veterinary Record, v.199, p.551-553, 1986.

BORGES, J.R.J.; PITOMBO, C.A.; SANTIAGO, S.S. et al., Incidência de afecções podais em bovinos leiteiros submetidos a diferentes sistemas de manejo. Arquivo da Escola de Medicina Veterinária da Bahia, v.15, n.1, p.34-42, 1992.

BORGES, N. C. Caracterização do fluido ruminal e dos parâmetros clínicos e laboratoriais de bovinos com pododermatite. Goiânia, 1998. 69p. Dissertação (Mestrado) Escola de Veterinária, Universidade Federal de Goiás.

BRIGAS-POULIM, M.; MEEK, A.H.; MARTIM, S.W. Interrelationships of health problems and age on milk production in selected Ontario Holsteins cows. Preventive Veterinary Medicine, v.8, p.15-24, 1990.

BUENO, V.F.F, NICOLAU, E. S., MESQUITA, A. J. et al., Mastite bovina clínica e subclínica, na região de Pirassununga, SP: Freqüência e redução na produção. Ciência Animal Brasileira, v.3, n.2, p.47 - 52, 2002.

BUENO, V.F.F, NICOLAU, E.S., MESQUITA, A.J. et al., Etiologia e suscetibilidade a antimicrobianos dos agentes da mastite bovina isolados na região de Pirassununga/SP - Brasil. Revista de Patologia Tropical, v.32, n.1, p.33 - 43, 2003. 
BUTLER, W.R., SMITH, R.D. Interrelationships between energy balance and postpartum reproductive function in dairy cattle. Journal of Dairy Science, v.72, p.767-777, 1989.

CARDOSO, M.V; SFORSIN, A.J.; SCARCELLI, S.R.; et al., Importância do diagnóstico diferencial em um surto de pneumonia enzoótica bovina. Arquivo do Instituto Biológico de São Paulo, v.69, n.3, p.11-113, 2002.

CHENOWETH, P.J.; LARSEN, R.E. Selection, use and management of natural service bulls. In: WILCOX, C.J.; VANHORNA, H.H. Large dairy herd management. Champaign IL: American Dairy Science Association, 1992.

COELHO, K.O.; SILVA, L.A.; MESQUITA, J.A. et al., Avaliação do efeito bactericida do hipoclorito de sódio para o uso em pedilúvios para bovinos In: CONGRESSO BRASILEIRO DE MEDICINA VETERINÁRIA, Salvador, 2001. Anais: Salvador: Associação Brasileira de Medicina Veterinária, 2001, p.28.

COELHO, K.O.; MACHADO, P. F; CORASSIN C.H. et al., Relação entre afecção do casco e produção de leite em vacas holandesas. In: CONGRESSO BRASILEIRO DE BUIATRIA, Salvador, 2003. Anais, Salvador: Associação Brasileira de Buiatria, 2003, p.127.

COLDEBELLA, A. Contagem de células somáticas e produção de leite em vacas holandesas confinadas . Piracicaba, 2003. 99p. Tese (Doutorado) - Escola Superior de Agricultura “Luiz de Queiroz”, Universidade de São Paulo.

COLEMAN, D.A.; THAIYNE, W.V.; DAILEY, R.A.; Factors affecting reproductive performance of dairy cows. Journal of Dairy Science, v.68, p.1793-1803, 1992.

COLLICK, D.W.; WARD, W.R.; DOBSON, H. Associations between types of lameness and fertility. Veterinary Record, v.125, p.103-106, 1989.

COLLIER, R.J. Effects of heat stress during pregnancy on maternal hormone concentration, calf birth wight and postpartum milk yield of holsteins cows. Journal of Dairy Science, v.54, p.309-319, 1982

CORREA, M.T.; ERB, H.; SCARLETT, J. Path analysis for seven postpartum disorders of holsteins cows. Journal of Dairy Science, v.76, p.1305-1312, 1993.

COSTA, C.N.; MILAGRES, J.C.; CASTRO, A.C.G. et al., Efeitos da estação e idade ao parto sobre a curva de lactação de vacas da raça holandesa. Revista da Sociedade Brasileira de Zootecnia, v.11, n.2, p.320-330, 1982. 
CULLOR, J.S. Mastitis and its influence upon reproductive performance in dairy cattle. In: SYMPOSIUM BOVINE MASTITIS, Indianapolis, 1990. Anais: Indianapolis: National Mastitis Council, 1990. p.56.

CULLOR, J.S.; TYLER, J.W.; SMITH, B.P. Tratado de medicina interna dos grandes animais. São Paulo: Manol 1993, p.620.

CURTIS, C.R.; ERB, H.N.; SNIFFEN, C.J. et al., Epidemiology of parturient paresis: Predisposing factors with emphasis on dry cow feeding and management. Journal of Dairy Science, v.67, p.817-820, 1984.

CURTIS, C.R.; ERB, H.N.; SNIFFEN, C.J. et al., Path analysis of dry period nutrition, postpartum metabolic and reproductive disorders, and mastitis in Holsteins cows. Journal of Dairy Science, v.68, p.2347-2359, 1985.

DADOUB, S.A.M.; SHOOK, G.E. Phenotypic relations among milk yield, somatic cell count, and clinical mastitis. Journal of Dairy Science, v.67, p.163-164, 1984.

DELUYKER, H.A.; GAY, J.M.; WEAVER, L.D.; MARKUSFELD, O. Interrelationships of somatic cell count, mastitis, and milk yield in a low somatic cell count herd. Journal of Dairy Science, v.76, p.3445-3452, 1990.

DETILLEUX, J.C.; GROHN, Y.T.; EICKER, S.W. Effects of left displaced abomasum on test day milk yield of Holsteins cows. Journal of Dairy Science, v.77, p.33163323, 1990.

DIRKSEN, G. Sistema Locomotor. In: ROSENBERGER, G. Exame clínico dos bovinos. Rio de Janeiro: Guanabara Koogan, 1993. p 315-340.

DOBSON, H.; ALAN, M.G.S. Preliminary investigations into the endocrine systems of subfertilite cattle: location of a common lesion. Journal of Endocrinology, v.113, p. 167-171, 1987.

DOHOO, I. R.; MARTIN, S. W. Disease, production and culling in Holstein-friesian cows. IV. Effects of disease on production. Preventive Veterinary Medicine, v.2, p.755-770, 1984.

DOMECQ, J.J.; SKIDMORE, A.L.; LLOYD, J.W. et al., Relationship between body condition scores and milk yield in large dairy herd of high yielding Holstein cows. Journal Animal Science, v.80, p.101-112, 1997. 
DRACKLEY, J.K. Biology of dairy cows during the transition period: The final frontier.. Journal Animal Science, v.82, p.2259-2273, 1999.

DUNN, T.G.; KALTENBACH, C.C. Nutrition and postpartum interval of the ewe, sow and cow. Journal of Animal Science, v.51, p.29-37, 1980.

EDMONDSON, A. J.; LEAN, I. J.; WEAVER, L. D.; et al., A body condition scoring chat for Holsteins dairy cows. Journal of Dairy Science, v.72, p.68, 1989.

EDMONDSON, P.W. Estratégias para a produção de leite de alta qualidade. In: CONGRESSO PANAMERICANO DE QUALIDADE DO LEITE E CONTROLE DE MASTITE, 2., Ribeirão Preto, 2002. Anais. São Paulo: Instituto Fernando Costa, 2002. p.46.

EICKER, S.W.; GROHN, Y.T.; HERTL, J.A. The associations between cumulative milk yield, days open, and days to first breeding in New York Holsteins Cows. Journal of Dairy Science, v.79, p.235-241, 1996.

EMANUELSON, U.; OLTENACU, P.A. Incidences and effects of diseases on the performance of Swedish dairy herds stratified by production. Journal of Dairy Science, v.81, p.2376-2383, 1998.

EVERET, R.W; CARTER, H.W. Accuracy of test interval method of calculating dairy herd improvement associations records. Journal of Dairy Science, v.51, n. 12, p.1936-1941, 1968.

FARIN, P.W.; SLENNING, B.D.; CORREA, M.T.; BRITT, J.H. Effects of calving season and milk yield on pregnancy risk and income in North Caroline Holsteins cows. Journal of Dairy Science, v.77, p.1848-1855, 1994.

FAUST, M.A.; MCDANIEL, B.T.; ROBINSON, O. et al., Environmental and yield effects on reproduction in primíparas Holsteins. Journal of Dairy Science, v.71, p.3092-3105, 1988.

FERNANDES, C.A.C. Alternativas para tratamento de retenção de placenta em gado de leite. Revista Brasileira de Reprodução Animal, v.23, p.442-444, 1999.

FERGUSSON, J. D. Body condition scoring. Advanced Dairy Cattle Nutrition Seminar. AABP, MN, 1992. 
FERGUNSON, J. D. Yield and reproductive in dairy cows. Bovine Practice, v.28, p. 79-82, 1994.

FERGUNSON, J.D., BYERS, D.; FERRY, J. et al., Roundtable discussion: body condition of lactation cows. Agri-Practice, v.15, p. 17-21, 1994.

FERREIRA, A.M.; SÁ, W.F.; VILLAÇA, H.A.; et al., Diagnóstico da situação produtiva e reprodutiva em rebanhos leiteiros da Zona da Mata, MG. Pesquisa Agropecuária Brasileira, v.27, p. 91-104, 1992.

FERREIRA, G.E.; FERNANDES, D.H. Parâmetros genéticos para características produtivas em bovinos da raça holandesa no Estado de Goiás. Revista Brasileira de Zootecnia, v.24, n.2, p.421-426, 2000.

FELTROW, J.; ANDERSON, K.; SEXTON, S. Herd composite somatic cell counts: average linear score and weighted average somatic cell score and milk production. Journal of Dairy Science, v.71, n.1, p.257-260, 1988.

FLEISHER, P., HOEDEMARKER, M; METZNER, M. et al., Clinical disorders in Holstein cows: Incidence and association among lactation risk factors. Acta Veterinária, v.70, n.2, p.157-165, 2001.

FONSECA, L. F. L.; SANTOS, M. V. Qualidade do leite e controle da mastite. São Paulo:Lemos ed, 2000. 141p.

FOURICHON, C.; BEAUDEAU, F.; SEEGERS, H. et al., Incidence of heath disorders in dairy farming systems in western France. Livestock Production Science, v.68, p.157-170, 2001.

FOX, L.K. Introduction to coliform mastitis. In: CALIFORN MASTITIS SYMPOSIUM. Washington, 1993. Anais Washington: State University, 1993. 56p.

FULKERSON, W.J. Reproduction in dairy cattle: effect of age, cow condition, production level, calving to first service interval and the male. Animal Reproduction Science, v.7, p.305-314, 1984.

FUQUAY, J.W., Heat stress at it affects calving animal production. Journal of Animal Science, v.52, p.164-174, 1981. 
GABRIEL, J.E.R.; OLIVEIRA, M.D.S.; TONHATI, H. et al., Análise de algumas características produtivas e reprodutivas da raça holandesa. In: REUNIÃO ANUAL DA SOCIEDADE BRASILEIRA DE ZOOTECNIA, 35., Botucatu, 1998. Anais. Botucatu: SBZ, 1998. v.5, p.56.

GANDINI, C.H.; KEOWN, J.F.; VLECK, L.D.V. Parâmetros genéticos das produções de leite, gordura e proteína, e do escore de células somáticas em 305 dias de lactação. In: REUNIÃO ANUAL DA SOCIEDADE BRASILEIRA DE ZOOTECNIA, 34., Juiz de Fora, 1997. Anais. Juiz de Fora: SBZ, 1997. v.3, p.4749.

GALVÃO, J.D.R. Avaliação do desempenho produtivo de rebanhos da raça pardo suíço no Estado de São Paulo. Lavras, 1993. 73p. Dissertação (Mestrado) - Universidade Federal de Lavras.

GARNSWORTHY, P.C. The effect of energy reserves at calving on performance of dairy cows. In: GARNSWORTHY. P.G. Nutrition And Lactation In Dairy Cow. Butterworths, Londres: Butterworths, 1988. 429p.

GASPARINO, E. Estudo de fatores genéticos e de meio que influenciam o desempenho de vacas mestiças à primeira cria. Viçosa, 1996. 112p. Dissertação (Mestrado) Universidade Federal de Viçosa.

GEARHART, M.A.; CURTIS, C.R.; ERB, H.N. et al., Relationships of changes in condition score to cow health in Holsteins. Journal of Dairy Science, v.73, p.1132-1142, 1990.

GEISHAUSER, T.; SHOUKRI, M.; KELTON, D. et al., Analysis of survivorship after displaced abomasum is diagnosed in dairy cows. Journal of Dairy Science, v.81, p.2346-3353, 1998.

GODDEN, S.M.; LISSEMORE, K.D.; KELTON, D.F. et al., Relationships between milk urea concentrations and nutritional management, production, and economic variables in Ontario dairy herds. Journal of Dairy Science, v.84, n.5, p.1128-1139, 2001.

GOFF, J.P.; HORST, R.L. Calcium salts for treating hipocalcemia: carrier effects, acidbase balance, and oral versus rectal administration. Journal of Dairy Science, v.80, p.1269-1280, 1995. 
GONZALEZ, F.H.D.; CAMPOS, R. Indicadores metabólico-nuticionais do leite. In: I SIMPÓSIO DE PATOLOGIA CLÍNICA VETERINÁRIA DA REGIÃO SUL DO BRASIL., Porto Alegre, 2003. Anais. Porto Alegre: Universidade Federal do Rio Grande do Sul, 2003, p.31-47.

GRAAF, T.A.; DWINGER, R.H. Estimation of production losses due to sub-clinical mastitis in dairy cattle in Costa Rica. Preventive Veterinary Medicine, v.26, p.215-222, 1996.

GREENOUGH, P.R. Ulceration of the sole in cattle. Agriculture Practice, p.17-22, 1986.

GROEHN, J.A.; KANEENE, J.B. Risk factors associated with lameness in lactating dairy cattle in Michigan. Preventive Veterinary Amsterdam, v.14, p. 77-85, 1992.

GRUMMER, R.R. Etiology of lipid-related metabolic disorders in periparturiente dairy cows. Journal of Dairy Science, v,76, n.2, p.3882-3886, 1993.

GUARD, C.L. Fresh cow problems are costly: culling hurts the most. Hoard's Dairyman, v.141, p.108-128, 1996.

GUARD, C.L. Doenças metabólicas uma abordagem de rebanho. In: REBUHN, W.C. Doenças do gado leiteiro. : Rio de Janeiro: Roca, 2000. 600 p.

GUSTAFSSON, A.H.; ANDERSSON, L.; EMANUELSON, U. Effect of hyperketonaemia, feeding frequency and intake of concentrate and energy on milk yield in dairy cows. Animal Production, v.56, p.51-60, 1993.

HAILE MARIAM, H.; BOWMAN, P.J.; GODDARD, M.E. Genetic and environmental correlations between test-day somatic cell count and milk yield traits. Livestock Production Science, v.73, p.1-13, 2001.

HARMON, R.J. Physiology of mastitis and factors affecting somatic cell counts. Journal of Dairy Science, v.77, n.7, p.2103-2112, 1994.

HARMON, R.J. Somatic cell counts: a primer. In: ANNUAL MEETING NATIONAL MASTITIS COUNCIL, 40., Reno, 2001. Proceedings. Madison: National Mastitis Council, 2001, p.3-9. 
HOLCOMB, C.S.; VAN HORN, H.H.; HEAD, H.H. et al., Effects of prepartum dry matter intake and forage percentage on postpartum performance of lactating dairy cows. Journal of Dairy Science, v.84, p.638-643, 2001.

HORST, R. L.; GOFF,J.P.; REINHARDT, T.A.; BRUXTON, D.R.; Strategies for preventing milk fever in dairy cattle. Journal of Dairy Science, v.79, p.11691180, 1990.

HORTET, P.; SEEGERS, H. Reduction in milk yield associated with somatic cell counts up to 600,000 cells $/ \mathrm{mL}$ in french Holsteins cows without clinical mastitis. Livestock Production Science, v.61, n.1, p.33-42, 1999.

HORTET, P.; BEAUDEAU, F.; SEEGERS, H. et al., Loos in milk and related composition changes resulting from clinical mastitis in dairy cows. Preventive Veterinary Medicine, v.37, p.1-20, 1998.

HUMPREY, W.D.; KALTENBACH, C.A.; DUNN, T.G. et al., Characterization of hormonal patterns in the beef cow during postpartum anestrus. Journal of Dairy Science, v.56, p.445-453, 1983.

INTERNATIONAL DAIRY FEDERATION. Recommended methods for somatic cell counting in milk. Brussels, 1984. 35p. (Bulletin, 168).

JOOSTEN, I.; HENSEN, P. Retained placenta: an imunological approach. Animal Reproduction Science, v.28, p. 451-461, 1987.

JOOSTEN, I.; VAN ELDIK, P.; ELVING, L. et al., Factors related to the etiology of retained placenta in dairy cattle. Animal Reproduction Science, v.14, p. 251-262, 1987.

KIRK, J.H. Programmable calculator program for linear somatic cell scores to estimate mastitis yield losses. Journal of Dairy Science, v.67, n.2, p.441-443, 1984.

KIRK, J.H.; BARTLETT, P.C. Economic impact of mastitis in Michigan Holstein dairy herds using a computerized records system. Agri-Practice, v.9, n.1, p.3-6, 1988.

KIRK, J.H.; DEGRAVES, F.; TYLER, J. Recent progress in treatment and control of mastitis in cattle. Journal of the American Veterinary Medical Association, v.24, p. 1152-1158, 1994. 
KUZMA, R. Treatment of cyclic ovarian disease in cows with low fertility. Bulletin of the Veterinary Institute in Pulawy, v. 38, n.1, p. 31-37, 1994.

LAGO, E.P.; PIRES, A.V.; SUSIN, I. et al., Efeito da condição corporal ao parto sobre alguns parâmetros do metabolismo energético, produção de leite e incidência de doenças no pós-parto de vacas leiteiras. Revista Brasileira de Zootecnia, v.30, n.5, p.1544-1549, 2001.

LAEVENS, H.; DELUYKER, H.; SCHUKKEN, Y.H. et al., Influence of parity and stage of lactation on the somatic cell count in bacteriologic ally negative dairy cows. Journal of Dairy Science, v.80, n.12, p.3219-3226, 1997.

LANGENGGER, J.; VIANI, M.C.R.; BAHIA, M.G. Efeito de agente etiológico da mastite subclínica sobre a produção de leite. Pesquisa Veterinária Brasileira, v.1, p. 47-52, 1981.

LEAN, I.J.; BRUSS, M.L; BALDWIN, R.L. et al., Bovine ketosis: 1 Epidemiological and pathogenesis. Veterinary Bulletin, v.61, p.1209-1218, 2001

LUCEY, S.; ROWLANDS, G.J. The association between clinical mastitis and milk yield in dairy cows. Animal Production, v.39, p.162-175, 1984.

LUCEY, S.; ROWLANDS, G.J.; RUSSELL, A. Short-term associations between disease and milk yield of dairy cows. Journal Dairy Research, v.53, p.7-15, 1986.

MACHADO, P.F.; BARANCELLI, G.; PEREIRA, A.R. CCS: Leite com mais qualidade e melhor rendimento industrial. Indústria de Laticínios, n.13, p.65-68, 1998.

MACHADO, P. F.; PEREIRA, A. R.; SARRIÉS, G. A. Efeitos da contagem de células somáticas na qualidade do leite e a atual situação de rebanhos brasileiros. Revista do Instituto de Laticínios Cândido Tostes, v.54, n.309, p.10-16, 1999.

MACHADO, P.F.; PEREIRA, A.R.; SILVA, L.F.P. et al., Células somáticas no leite em rebanhos brasileiros. Scientia Agrícola, v.57, n.2, p.359-361, 2000.

MARKUSFELD, O. Periparturiente traits in seven high dairy herds: incidence rates, association with parity, and interrelationships among traits. Journal of Dairy Science, v.70, p.158-164, 1990. 
MARKUSFELD, O.; EZRA, E. Body measurements, metritis, and postpartum performance of fist lactation cows. Journal of Dairy Science, v.76, p.3771-3777, 1993.

MARTIN, J.M.; WILCOX, C.J.; MOYA, J. et al., Effects of retained fetal membranes on milk yield and reproductive performance. Journal of Dairy Science, v.69, p.1166-1168, 1986.

MEYER, P.M. Fatores não nutricionais que afetam as concentrações de nitrogênio uréico no leite. Piracicaba, 2003. 131p. Tese (Doutorado) - Escola Superior de Agricultura “Luiz de Queiroz”, Universidade de São Paulo.

MILAGRES, J.C.; ALVES, A.J.R.; PEREIRA, J.C. et al., Influência de fatores genéticos e de meio ambiente sobre a produção de leite de raças mestiças holandesa. Revista da Sociedade Brasileira de Zootecnia, v.17, n.4, p.341-357, 1988.

MILLER, R.H.; PAAPE, M.J.; FULTON, L.A. The relationship of milk somatic cell count to milk yields for Holsteins heifers after first calving. Journal of Dairy Science, v.76, p.728-733, 1993.

MIENTTINEM, P.; SETALA, J.J. Relação entre cetose subclínica, produção de leite e fertilidade no gado leiteiro. Medicina Veterinária Preventiva, v.17, n.1, p.1-8, 1993.

MOISER, D.A. Bacterial pneumonia. Veterinary Clinical North American Food Animal Practice, v.13, n.3, p.483-493, 1997.

MOLINA, L.R.; CARVALHO, A.U.; FACURY-FILHO, E.J. et al., Prevalência e classificação das afecções podais em vacas lactantes na bacia leiteira de Belo Horizonte. Arquivo Brasileiro de Medicina Veterinária e Zootecnia, v.51, n.2, p.149- 152, 1999.

MOORE, D.A; CULLOR, R.H; SISCHO, W.M. Preliminary field evidence for the association of clinical mastitis with altered us intervals in dairy cattle. Theriogenology, v.36, p.257-265, 1991.

MORAES, R.R. Caracterização clínica laboratorial e anatomopatológica da fase inicial da inflamação do tecido interdigital de bovinos da raça girolanda. Goiânia, 2000. 110p. Dissertação (Mestrado) - Escola de Veterinária, Universidade Federal de Goiás. 
MURPHY M.G.; BOLAND, M.P.; ROCHE, J.F. Pattern of follicular growth and resumption of ovarian activity in postpartum beef suckled cows. Journal of Reproduction and Fertility, v.90, p.523-533, 1990.

NEBEL, L.R.; MCGILLARD, M.L. Interaction of high yields and reproductive performance in dairy cows. Journal of Dairy Science, v.76, n.10, p.3257-3268, 1993.

NICOLAU, E.S.; NADER FILHO, A.; AMARAL, L.A. et al., Influência da mastite subclínica estafilocócica sobre a produção láctea dos quartos afetados. ARS Veterinária, v.8, n.2, p.118-124, 1992.

NICKERSON, S.C. Immune mechanisms of the bovine udder: An overview. Journal of the American Veterinary Medical Association, v.187, n.1, p.41-45, 1985.

NOBRE, P.R.C.; MILAGRES, J.C.; CASTRO, A.C. Fatores genéticos e de meio ambiente que afetam a produção de leite. Revista da Sociedade Brasileira de Zootecnia, v.13, n.3, p.334-346, 1984.

NOCEK, J.E. Hoof cares for dairy cattle. Fort Atkinson: Ed. W. D. Hoard, 1993, 32p.

NOCEK, J.E. Bovine acidosis: Implications on laminitis. Journal of Dairy Science, v.80, p.1005-1028, 1997.

PARK, Y.H.; JACOBSON, N. Glândula mamária e lactação. In: SWENSON, M.J.; REECE, W. O. Fisiologia dos animais domésticos. Rio de Janeiro: Guanabara Koogan, 1996, p.645-659.

PATTON, R.A.; BUCHOLTZ, H.F.; SCHIMIDT, M.K. et al., Body condition scoring: a management. Dairy guide, east lasing, Michigan, p. 6, 1988.

PEDRON, O., CHELI, F., SENATORE, E. et al., Effect of body condition score at calving on performance, some blood parameters, and milk fatty acid composition in dairy cows. Journal of Dairy Science, v.76, n.9, p.2528-2535, 1993.

PEELER, E.J.; OTTE, M.J.; ESSLEMONT, R.J. Interrelationship of periparturiente diseases in dairy cows. Veterinary Record, v.128, p.129-132, 1994.

PEREIRA, A.R. Contagem de células somáticas e características produtivas de vacas em lactação da raça holandesa. Piracicaba, 2000. 53p. Dissertação (Mestrado) Escola Superior de Agricultura “Luiz de Queiroz”, Universidade de São Paulo. 
PHILPOT, W.N. Importância da contagem de células somáticas e outros fatores que afetam a qualidade do leite. In: SIMPÓSIO INTERNACIONAL SOBRE QUALIDADE DO LEITE, 1., Curitiba, 1998. Anais. Curitiba: UFPR, 1998. p.2835.

PHILPOT, W.N. Qualidade do leite e controle de mastite: passado, presente e futuro. In: CONGRESSO PANAMERICANO DE QUALIDADE DO LEITE E CONTROLE DE MASTITE, 2., Ribeirão Preto, 2002. Anais. São Paulo: Instituto Fernando Costa, 2002. p.23-38.

PIRES, A.V. Distúrbios nutricionais. In : PEIXOTO, A . M; MOURA, J.C; FARIA, V.P. Confinamento de bovinos leiteiros. Piracicaba: FEALQ, 1993. p. 267-283.

PURSLEY, J.R.; SILCOX, R.W.; WITTBANK, M.C. Effect of timed AI on pregnancy rates, calving rates, pregnancy loss, and gender ratio after synchronization of ovulation in lactating dairy cows. Journal of Dairy Science, v.81, p.2139-2144, 1998

RAIZMAN, E.A.; SANTOS, J.E.P. The effect of left displacement of abomasum corrected by toggle-pin suture on lactation, reproduction, and health of Holstein dairy cows, Journal of Dairy Science, v.85, p. 1157-1164, 2002.

RAJALA-SCHULTZ, P.J.; Y.T.GROHN. Disease occurrence and risk factors analysis in Finnish Ayrshire cows. Acta Veterinaria Scandinavia, v.39, p.1-13, 1998.

RAJALA-SCHULTZ, P.J.; Y. T. GROHN. Effects of milk fever, ketosis, and lameness on milk in dairy cows. Journal of Dairy Science, v. 82, p.288-294, 1999.

RAMOS, L.S. Avaliação econômica dos efeitos da pododermatite sobre a reprodução e produção dos bovinos. Goiânia, 1999. 113 p. Dissertação (Mestrado) - Escola de Veterinária, Universidade Federal de Goiás.

RAMOS, L.S. ; SILVA, L.A.; MEIRINHOS, M.L. G et al., Avaliação de parâmetros reprodutivos em fêmeas bovinas de aptidão leiteira portadoras de pododermatite necrosante, ARS Veterinária, v.17, n.2, p. 98-106, 2001.

RANDEL, R.D. Nutrition and postpartum rebreeding in cattle. Journal of Dairy Science, v.68, p.853-862, 1990.

RAUBERTAS, R.F.; SHOOK, G.E. Relationship between lactation measures of somatic cell concentration and milk yield. Journal of Dairy Science, v.65, n.3, p.419-425, 1982. 
REBHUN, W.C. Diseases of dairy cattle. Media: Williams \& Wilkins, 2000. 630p.

REIS, R.B.; SILVA, H.M. Influência de alguns fatores de meio sobre as principais características produtivas em rebanho holandeses. Arquivo Brasileiro de Medicina Veterinária e Zootecnia, v.37, n.2, p. 273-290, 1997.

RENEAU, J.K. Effective use of dairy herd improvement somatic cell counts in mastitis control. Journal of Dairy Science, v.69, n.6, p.1708-1720, 1986.

RIBAS, N.P.; PAULA, M.C.; ANDRADE, U.V.C. Somatic cell count and somatic cell score bulk tank milk samples. In: CONGRESSO PANAMERICANO DE QUALIDADE DO LEITE E CONTROLE DE MASTITE, 2., Ribeirão Preto, 2002. Anais. São Paulo: Instituto Fernando Costa, 2002. p.68.

RICSHTER, G.O.; RIBAS, N.P.; MONARDES, H.G. et al., Estudo da produção de leite, produção de gordura e porcentagem de gordura em vacas holandesas, Revista do Setor de Ciências Agrárias, v.14, n.1, p-141-149, 1995.

RISCO, C.A. Calving related disorders. In: WILCOX, C.J.; VANHORNA, H.H. Large Dairy Herd Management. IL: Champaign: American Dairy Science Association, 1992. p.193-201.

ROWLANDS, G.L; LUCEY, S. Changes in milk yield in dairy cows associated with metabolic and reproductive diseases and lameness. Preventive Veterinary Medicine, v.4, p. 205-221, 1986.

RUEGG, P.L; GOODGER, W.J.; HOLBERG, C.A. et al., Relation among body condition score, serum urea nitrogen and cholesterol concentrations, and reproductive performance in high-producing Holsteins dairy cows in early lactation. American Journal of Veterinary Research, v.53, p. 312-325, 1992.

RUEGG, P.L.; MILTON, R.L. Body condition scores of Holstein cows on Prince Edward Island, Canada: relationships with yield, reproductive performance, and disease. Journal of Dairy Science, v.78, p.552, 1995.

SANTOS, J.E.P.; CERRI, R.L.A; KIRK, J.H. Effect of clinical mastitis incidence on lactation and reproductive performance of Holstein dairy cows In: CONGRESSO PANAMERICANO DE QUALIDADE DO LEITE E CONTROLE DE MASTITE, 2., Ribeirão Preto, 2002. Anais. São Paulo: Instituto Fernando Costa, 2002, p. 57. 
SANTOS, J.E.P.; CERRI, R.L.A; KIRK, J.H. Effect of clinical mastitis incidence on lactation and reproductive performance of Holstein dairy cows. Animal Reproduction Science, v.58, p.312-327, 2003.

SANTOS, M.V. Efeito da mastite sobre a qualidade do leite e dos derivados lácteos. In: CONGRESSO PANAMERICANO DE QUALIDADE DO LEITE E CONTROLE DE MASTITE, 2., Ribeirão Preto, 2002. Anais. São Paulo: Instituto Fernando Costa, 2002. p.179-188.

SANTOS, R.L. Dinâmica ovariana e crescimento folicular. Veterinária Notícias, v.3, n.1, p. 159-167, 1996.

SAS Institute. SAS/STAT User's Guide 8.0. (compact disc). Cary: SAS Institute, 1999.

SCHLATTER, L. The addition of nutrocal to the diets of periparturiente cows: A review. Des Moines: Kemin Industries, 1997, p.1-11.

SCHRICK, F.N.; HOGAN, J.S., SAXTON, A.M. et al., Influence of sub clinical mastitis during early lactation on reproductive parameters. Journal of Dairy Science, v.84, p. 1407-1412, 2001.

SHEARER, J.K.; VAN HORN, H.H. The effect of left displacement of abomasum on lactation, and reproductive performance of Holstein dairy cows, Journal of Dairy Science, v.81, p. 2346-2350, 1998.

SHELDON, M. Bovine Fertility - Practical implications of the maternal recognition of pregnancy. Farm Animal Practice, v.5, p. 546-554, 1997.

SHOOK, G. E. A linear scale for scoring somatic cell count. Journal of Dairy Science, v.65, suppl.1, p. 108, 1982.

SHOOK, G. E. Breeding, selection and somatic cell counts: where are we today? In: ANNUAL MEETING NATIONAL MASTITIS COUNCIL, 40., Reno, 2001. Proceedings. Madison: National Mastitis Council. p.113-127.

SHORT, R.E.; ADAMS, D.C. Nutritional and hormonal interrelationship in beef cattle reproduction. Canadian Journal of Animal Science, v.68, p.39-39, 1988.

SIMERL, N.A.; WILCOX, C.J.; THATCHER, W.W. Postpartum performance of dairy heifers freshening at young ages. Journal of Dairy Science, v.75, p.590-595, 1992. 
SILVA, C.A. Identificação e isolamento do D. Nodusus e do F. Necrophorum de bovinos portadores de pododermatite, relação com a etiopatogenia, dados edafoclimáticos e avaliações do tratamento. Goiânia, GO. 1997. 78p. Dissertação (Mestrado)-Escola de Veterinária, Universidade Federal de Goiás.

SILVA, H.M.; WILCOX, C.J.; THATCHER, W.W. et al., Factors affecting days open, gestation length, and calving interval in Florida dairy cattle. Journal of Dairy Science, v.75, p.288-294, 1992.

SILVA, L. A.; COELHO, K.O.; MESQUITA, A.J. et al., The effects sodium hypochlorite on mesophilic aerobic bacteria of the interdigital space of healthy cattle. Israel Journal of Veterinary Medicine, v. 57, n.3, p. 37-41, 2002

SORENSEN, J.T.; ENEVOLDSEN, C. Effect of dry period length on milk production in subsequent lactation. Journal of Dairy Science, v.74, p.1277-1283, 1991.

STENGARDE, L.U.; DELUYKER, H.A.; AZARI, A.S. Effects of management, feeding, and treatment on clinical and biochemical variables in cattle with displaced abomasum. American Journal Veterinary Research, v.63, n.1, p. 345-357, 2002.

THATCHER, C. D.; COLIER, Effects of nutrition and management of the dry and fresh cow on fertility. Bovine Practitioner, v.21, p.172-179, 1986.

VAN WERVEN, T., SCHUKKEN, Y.H. LLOYD, J. et al., The effects of duration of retained placenta on reproduction, milk production, postpartum disease and culling rate. Theriogenology, v.37, p.1191-1203, 1992.

WATTS, J. L. Etiological agents of bovine mastitis. Veterinary Microbiology, v.16, n.1, p.41-66, 1988.

WILDMAN, E.E.; JONES, G.M.; WAGNER, P.E. et al., A dairy cow body condition scoring system and its relationship to select production characteristics. Journal of Dairy Science, v.65, p.495-501, 1982.

WILSON, J.D.; GONZALEZ, R.N.; DAS, H.H. Bovine mastitis pathogens in New York and Pennsylvania: prevalence and effects on somatic cell count and milk production. Journal of Dairy Science, v.80, n.10, p.2592-2598, 1997.

WILSON, J.D.; SEARS, P.M. Clinical mastitis caused by different types of pathogens: differences in milk production loss, recovery, age at onset, and milk NAGase. Agripractice, v.13, n.8, p.13-21, 1992. 
WITAKER, D.A.; KELLY, J.M, SMITH, E.J. Incidence of lameness in dairy cows. Veterinary Record, v.113, p. 60-62, 1983. 